\title{
Investigating the links between ozone and organic aerosol chemistry in a biomass burning plume from a prescribed fire in California chaparral
}

\author{
M. J. Alvarado ${ }^{1}$, C. R. Lonsdale ${ }^{1}$, R. J. Yokelson ${ }^{2}$, S. K. Akagi ${ }^{2}$, H. Coe $^{3}$, J. S. Craven ${ }^{4}$, E. V. Fischer ${ }^{5}$, \\ G. R. McMeeking ${ }^{5}$, J. H. Seinfeld ${ }^{4}$, T. Soni ${ }^{1, *}$, J. W. Taylor ${ }^{3}$, D. R. Weise ${ }^{6}$, and C. E. Wold ${ }^{7}$ \\ ${ }^{1}$ Atmospheric and Environmental Research, Lexington, MA, USA \\ ${ }^{2}$ Department of Chemistry, University of Montana, Missoula, MT, USA \\ ${ }^{3}$ Centre for Atmospheric Science, University of Manchester, Manchester, United Kingdom \\ ${ }^{4}$ Division of Chemistry and Chemical Engineering, California Institute of Technology, Pasadena, CA, USA \\ ${ }^{5}$ Department of Atmospheric Science, Colorado State University, Fort Collins, CO, USA \\ ${ }^{6}$ PSW Research Station, USDA Forest Service, Riverside, CA, USA \\ ${ }^{7}$ Fire Sciences Laboratory, United States Department of Agriculture (USDA) Forest Service, Missoula, MT, USA \\ *now at: Shell Chemical LP, Houston, TX, USA
}

Correspondence to: M. J. Alvarado (malvarad@aer.com)

Received: 8 November 2014 - Published in Atmos. Chem. Phys. Discuss.: 22 December 2014

Revised: 30 April 2015 - Accepted: 25 May 2015 - Published: 17 June 2015

\begin{abstract}
Within minutes after emission, complex photochemistry in biomass burning smoke plumes can cause large changes in the concentrations of ozone $\left(\mathrm{O}_{3}\right)$ and organic aerosol (OA). Being able to understand and simulate this rapid chemical evolution under a wide variety of conditions is a critical part of forecasting the impact of these fires on air quality, atmospheric composition, and climate. Here we use version 2.1 of the Aerosol Simulation Program (ASP) to simulate the evolution of $\mathrm{O}_{3}$ and secondary organic aerosol (SOA) within a young biomass burning smoke plume from the Williams prescribed fire in chaparral, which was sampled over California in November 2009. We demonstrate the use of a method for simultaneously accounting for the impact of the unidentified intermediate volatility, semi-volatile, and extremely low volatility organic compounds (here collectively called "SVOCs") on the formation of OA (using the Volatility Basis Set - VBS) and $\mathrm{O}_{3}$ (using the concept of mechanistic reactivity). We show that this method can successfully simulate the observations of $\mathrm{O}_{3}, \mathrm{OA}, \mathrm{NO}_{x}$, ethylene $\left(\mathrm{C}_{2} \mathrm{H}_{4}\right)$, and $\mathrm{OH}$ to within measurement uncertainty using reasonable assumptions about the average chemistry of the unidentified SVOCs. These assumptions were (1) a reaction rate constant with $\mathrm{OH}$ of $\sim 10^{-11} \mathrm{~cm}^{3} \mathrm{~s}^{-1}$; (2) a significant fraction (up
\end{abstract}

to $\sim 50 \%$ ) of the $\mathrm{RO}_{2}+\mathrm{NO}$ reaction resulted in fragmentation, rather than functionalization, of the parent SVOC; (3) $\sim 1.1$ molecules of $\mathrm{O}_{3}$ were formed for every molecule of SVOC that reacted; (4) $\sim 60 \%$ of the $\mathrm{OH}$ that reacted with the unidentified non-methane organic compounds (NMOC) was regenerated as $\mathrm{HO}_{2}$; and (5) that $\sim 50 \%$ of the $\mathrm{NO}$ that reacted with the SVOC peroxy radicals was lost, presumably to organic nitrate formation. Additional evidence for the fragmentation pathway is provided by the observed rate of formation of acetic acid $\left(\mathrm{CH}_{3} \mathrm{COOH}\right)$, which is consistent with our assumed fragmentation rate. However, the model overestimates peroxyacetyl nitrate (PAN) formation downwind by about $50 \%$, suggesting the need for further refinements to the chemistry. This method could provide a way for classifying different smoke plume observations in terms of the average chemistry of their SVOCs, and could be used to study how the chemistry of these compounds (and the $\mathrm{O}_{3}$ and $\mathrm{OA}$ they form) varies between plumes. 


\section{Introduction}

Biomass burning is a major source of atmospheric trace gases and particles that impact air quality and climate (e.g., Crutzen and Andreae, 1990; van der Werf, 2010; Akagi et al., 2011). Within minutes after emission, rapid and complex photochemistry within the young biomass burning smoke plumes can lead to significant increases in the concentrations of secondary pollutants such as ozone $\left(\mathrm{O}_{3}\right.$; e.g., Mauzerall et al., 1998; Goode et al., 2000; Hobbs et al., 2003; Pfister et al., 2006; Lapina et al., 2006; Val Martin et al., 2006; Yokelson et al., 2009; Jaffe and Widger, 2012; Akagi et al., 2012, 2013), peroxyacetyl nitrate (PAN; e.g., Jacob et al., 1992; Alvarado et al., 2010, 2011; Fischer et al., 2014), and organic aerosol (OA; e.g., Hobbs et al., 2003; Grieshop et al., 2009a, b; Yokelson et al., 2009; Hennigan et al., 2011; Heringa et al., 2011; Vakkari et al., 2014), while other smoke plumes can show little to no formation of $\mathrm{O}_{3}$ (e.g., Alvarado et al., 2010, Zhang et al., 2014) or OA (e.g., Akagi et al., 2012). Understanding the atmospheric chemistry of these young smoke plumes, conditions of which can lead to the secondary formation of $\mathrm{O}_{3}$, PAN, and $\mathrm{OA}$, is thus critical to understanding the impact of these plumes on atmospheric composition and the resulting impacts on air quality, human health, and climate. However, global- and regional-scale Eulerian models of atmospheric chemistry artificially dilute biomass burning emissions into large-scale grid boxes, which can result in large errors in the predicted concentrations of $\mathrm{O}_{3}$ and aerosol species downwind (e.g., Alvarado et al., 2009; Zhang et al., 2014). In contrast, plume-scale Lagrangian models allow us to examine the chemical and physical transformations within these concentrated plumes in detail and can be used to develop parameterizations for this aging process for coarser models (e.g., the parameterizations of Vinken et al., 2011, and Holmes et al., 2014, for ship plumes).

Our understanding of the formation of ozone within biomass burning plumes is still poor, due both to the limited observational data available on $\mathrm{O}_{3}$ formation in smoke plumes and the highly variable results seen in the available observations. Several aircraft and surface studies of the chemistry of young biomass burning smoke plumes have found significant formation of $\mathrm{O}_{3}$ within smoke plumes. For example, Baylon et al. (2014) reported $\Delta \mathrm{O}_{3} / \Delta \mathrm{CO}$ from 0.4 to $11 \%$, corresponding to $\mathrm{O}_{3}$ enhancements of 3.8 to $32 \mathrm{ppbv}$ in 19 wildfire plumes samples at Mt. Bachelor Observatory. They note that plumes that have low values of $\Delta \mathrm{O}_{3} / \Delta \mathrm{CO}$ can still correspond to significant $\mathrm{O}_{3}$ enhancements in concentrated plumes, with one event with a $\Delta \mathrm{O}_{3} / \Delta \mathrm{CO}$ value of $0.81 \%$ corresponding to an $\mathrm{O}_{3}$ enhancement of $17 \mathrm{ppbv}$. Akagi et al. (2013) found significant $\mathrm{O}_{3}$ formation $\left(\Delta \mathrm{O}_{3} / \Delta \mathrm{CO}\right.$ from 10 to $90 \%$ ) within $2 \mathrm{~h}$ for all of the South Carolina prescribed fires studied; Parrington et al. (2013) found values of $\Delta \mathrm{O}_{3} / \Delta \mathrm{CO}$ increased from $2.0 \pm 0.8 \%$ in boreal biomass burning plumes less than 2 days old over eastern Canada to $55 \pm 29 \%$ in plumes that were more than 5 days old. Sim- ilarly, Andreae et al. (1994) found that aged plumes (over 10 days old) from the biomass burning regions of South America and Africa had $\Delta \mathrm{O}_{3} / \Delta \mathrm{CO}$ values between 20 and $70 \%$. However, other studies, mainly in boreal regions, have found little formation or even depletion of $\mathrm{O}_{3}$ in some young biomass burning plumes (e.g., Alvarado et al., 2010). This low- $\mathrm{O}_{3}$ formation is likely due to a combination of low emissions of $\mathrm{NO}_{x}$ from the boreal fires (Akagi et al., 2011), sequestration of $\mathrm{NO}_{x}$ in PAN and other organic nitrates (e.g., Jacob et al., 1992; Alvarado et al., 2010, 2011), and reduced rates of photochemical reactions due to aerosol absorption and scattering (e.g., Jiang et al., 2012). Similarly, some studies have shown that fires can contribute to high surface $\mathrm{O}_{3}$ events that exceed the USA air quality standard for $\mathrm{O}_{3}$ (e.g., Jaffe et al., 2013), while other studies suggest that this enhanced surface $\mathrm{O}_{3}$ is only present when the biomass burning emissions mix with anthropogenic pollution (Singh et al., 2012; Zhang et al., 2014). However, even given the observed variability among fires, it is likely that biomass burning has an impact on the concentrations of tropospheric $\mathrm{O}_{3}$. For example, the recent review of Jaffe and Widger (2012) estimated that biomass burning could contribute $170 \mathrm{Tg}$ of $\mathrm{O}_{3}$ per year, accounting for $3.5 \%$ of all global tropospheric $\mathrm{O}_{3}$ production. However, Sudo and Akimoto (2007) estimated that over a third of tropospheric $\mathrm{O}_{3}$ came from free tropospheric chemical production due to biomass burning outflow from South America and South Africa.

The $\mathrm{NO}_{x}$ emitted by biomass burning is rapidly converted into a wide variety of inorganic nitrate (i.e., $\mathrm{HNO}_{3(\mathrm{~g})}$ and total aerosol inorganic nitrate, or $\mathrm{NO}_{3(\mathrm{p})}$ ) and organic nitrate species (i.e., alkyl nitrates $\left(\mathrm{RONO}_{2}\right)$ and peroxy nitrates $\left(\mathrm{RO}_{2} \mathrm{NO}_{2}\right)$, including PAN; Jacob et al., 1992; Yokelson et al., 2009; Alvarado et al., 2010, 2011; Akagi et al., 2012). The rate at which this conversion occurs and the relative production of inorganic nitrate, alkyl nitrates, and peroxy nitrates are a key control of the impact of the biomass burning on $\mathrm{O}_{3}$ production and atmospheric composition. Once $\mathrm{NO}_{x}$ is converted to inorganic or organic nitrate, it is generally unavailable for further $\mathrm{O}_{3}$ formation near the fire source. Furthermore, while conversion of $\mathrm{NO}_{x}$ into inorganic nitrate $\left(\mathrm{HNO}_{3(\mathrm{~g})}+\mathrm{NO}_{3(\mathrm{p})}\right)$ is generally irreversible (except for the slow reaction of $\mathrm{HNO}_{3(\mathrm{~g})}$ with $\mathrm{OH}$ ), peroxy nitrate species like PAN can act as thermally unstable reservoirs of $\mathrm{NO}_{x}$, allowing transport of $\mathrm{NO}_{x}$ in the upper atmosphere far from the original source and then producing $\mathrm{NO}_{x}$ via thermal decomposition as the air mass descends to the surface (e.g., Fischer et al., 2010). This regenerated $\mathrm{NO}_{x}$ can thus impact $\mathrm{O}_{3}$ formation far from the original source.

In addition, photochemistry within the smoke plume can rapidly oxidize non-methane organic compounds (NMOCs), both those that were emitted in the gas phase and those emitted in the particle phase, lowering their vapor pressure and thus leading to the formation of secondary organic aerosol (SOA). As with $\mathrm{O}_{3}$ and PAN formation, the formation of SOA in smoke plumes is highly variable, with the ratio of 
OA to $\mathrm{CO}_{2}$ increasing by a factor of $2-3$ downwind of some biomass burning fires (e.g., Hobbs et al., 2003; Grieshop et al., 2009a, b; Yokelson et al., 2009; Hennigan et al., 2011; Heringa et al., 2011; Vakkari et al., 2014), while in others it can stay constant or even decrease (e.g., Capes et al., 2008; Akagi et al., 2012). For cases where little net SOA formation was observed, it is likely that the NMOCs were still being oxidized. However, in these cases the fragmentation of the organic species after oxidation (leading to higher volatility products) is likely more common than functionalization (i.e., the addition of oxygen to the organic species, leading to lower volatility products).

Plume-scale Lagrangian parcel models can be used to investigate the evolution of $\mathrm{O}_{3}, \mathrm{PAN}$, and $\mathrm{OA}$ in smoke plumes in detail, as their relatively simple parameterizations of plume dispersion and transport allow detailed simulation of the chemical and microphysical processes taking place within the young smoke plumes (e.g., Mauzerall et al., 1998; Mason et al., 2001, 2006; Jost et al., 2003; Trentmann et al., 2005; Alvarado and Prinn, 2009; Heilman et al., 2014; Arnold et al., 2015). Previous plume-scale modeling studies have greatly advanced our understanding of these transformations. Mauzerall et al. (1998) found that $\mathrm{O}_{3}$ production within biomass burning plumes was limited by the concentration of $\mathrm{NO}_{x}$ and that the formation and subsequent degradation of PAN helped to maintain $\mathrm{NO}_{x}$ concentrations. Mason et al. (2001) and Trentmann et al. (2003) showed that oxygenated volatile organic compounds (OVOCs) were critical to the formation of $\mathrm{O}_{3}$ within the smoke plumes. More recent work has suggested heterogeneous chemistry and currently unidentified organic species as potential explanations for the rapid formation of $\mathrm{O}_{3}$ and organic aerosol seen within some smoke plumes (Trentmann et al., 2005; Mason et al., 2006; Alvarado and Prinn, 2009).

The Aerosol Simulation Program (ASP) was developed to simulate the formation of ozone and SOA within young biomass burning plumes (Alvarado, 2008). ASP v1.0 was used to simulate several African and North American plumes (Alvarado and Prinn, 2009) and to simultaneously simulate the chemistry, dynamics, and radiative transfer within a smoke plume using a high-resolution threedimensional plume model (Alvarado et al., 2009). Alvarado and Prinn (2009) showed while their initial ASP v1.0 simulations underestimated the formation of both $\mathrm{OH}$ and $\mathrm{O}_{3}$ in the Timbavati savannah fire smoke plume (Hobbs et al., 2003), if the $\mathrm{OH}$ concentration in ASP v1.0 was fixed at the estimated value of $1.7 \times 10^{7}$ molecules $\mathrm{cm}^{-3}$ then the model reproduced the observed concentrations of $\mathrm{O}_{3}$. This suggested that the model was missing an important source of $\mathrm{OH}$, and they proposed a heterogeneous reaction of $\mathrm{NO}_{2}$ on aerosol particles producing $\mathrm{HONO}$, followed by the photolysis of HONO into $\mathrm{NO}$ and $\mathrm{OH}$, as a candidate for the missing source of $\mathrm{OH}$ within the smoke plume. Alvarado and Prinn (2009) also found that including only SOA formation from known SOA precursors (mainly aromatic species like toluene) underesti- mated the concentrations of organic aerosol observed downwind by $\sim 60 \%$, suggesting that the model was missing a large source of SOA. They proposed that the large amount of gas-phase organic compounds that were unidentified by the then current measurement techniques (Christian et al., 2003; Warneke et al., 2011) could include the precursors for the missing SOA. Assuming these compounds had SOA yields similar to monoterpenes gave the observed SOA formation.

In this paper, we describe recent updates to the gas-phase chemistry and SOA formation modules in ASP. We use this updated version (ASP v2.1) to simulate the chemical evolution of a young biomass burning smoke plume sampled over California in November near San Luis Obispo (the Williams fire; Akagi et al., 2012). The analysis of the $\mathrm{O}_{3}$, PAN, and OA evolution in biomass burning plumes is complicated by the fact that a large fraction ( $30-50 \%$ by carbon mass; Christian et al., 2003; Warneke et al., 2011) of the NMOCs present in smoke plumes are unidentified, and thus their oxidation chemistry is not well known.

Furthermore, while there was clear secondary formation of $\mathrm{O}_{3}$ and PAN within the Williams fire plume, the dilutioncorrected amount of OA in the plume decreased slightly (Akagi et al., 2012). Most current methods for modeling the OA evolution in smoke plumes lead to significant secondary growth of the OA (e.g., Grieshop et al., 2009a), but we need instead to modify ASP v2.1 to simulate both this slight loss of $\mathrm{OA}$ and the chemical formation of $\mathrm{O}_{3}$, PAN, and other gas-phase species.

Here we present a method for simultaneously accounting for the impact of the unidentified organic compounds (here collectively called "SVOCs") on the formation of OA and $\mathrm{O}_{3}$, drawing on the volatility basis set (VBS) approach (e.g., Robinson et al., 2007) for modeling OA and the concept of the mechanistic reactivity of a mixture of organic compounds (e.g., Carter, 1994). We show that this method can successfully simulate the Williams fire plume observations using reasonable assumptions about the chemistry of the unidentified SVOCs.

Section 2 describes the updates to the gas-phase chemistry and SOA formation modules of ASP for version 2.1. Section 3 discusses our validation of the gas-phase chemistry in ASP v2.1 against data from a smog chamber (Carter et al., 2005). Section 4 describes the Williams fire and summarizes the available observations of the smoke plume from Akagi et al. (2012). Section 5 discusses the results of the ASP simulation of the Williams fire, including sensitivity tests to investigate the chemistry of the unidentified SVOCs and their impacts on $\mathrm{O}_{3}$, PAN, other trace gases, and OA, while Sect. 6 gives the conclusions of our study and directions for future work. 


\section{Updates to the Aerosol Simulation Program}

An overview of ASP v1.0 is given by Alvarado and Prinn (2009), and the routines are described in detail in Alvarado (2008). Here we briefly discuss the modules of ASP that have not changed since Alvarado and Prinn (2009) in Sect. 2.1 before describing the updates to the gas-phase chemistry (Sect. 2.2) and SOA formation (Sect. 2.3) routines for ASP v2.1.

\subsection{ASP modules}

Aerosols are represented in ASP by a single moving-center sectional size distribution, where the aerosol concentrations are distributed over increments in radius space (Jacobson, 1997, 2002, 2005). ASP includes modules to calculate aerosol thermodynamics, gas-to-aerosol mass transfer (condensation/evaporation), and coagulation of aerosols. The thermodynamics module in ASP uses the mass flux iteration (MFI) method of Jacobson (2005) to calculate the equilibrium concentration of gas and aerosol species. Equilibrium constants for the inorganic electrolyte reactions match those of Fountoukis and Nenes (2007). Binary activity coefficients of inorganic electrolytes are calculated using the KusikMeissner method (Kusik and Meissner, 1978; Resch, 1995), as are the mean activity coefficients. The water content of inorganic aerosols is calculated with an iterative routine that calculates water activities for aqueous solutions of a single electrolyte using a formula based on the Gibbs-Duhem equation (Steele, 2004). Steele (2004) and Alvarado (2008) found this approach compares well with other inorganic aerosol thermodynamics models such as ISORROPIA (Nenes et al., 1998; Fountoukis and Nenes, 2007).

Mass transfer between the gas and aerosol phases is calculated in ASP using a hybrid scheme where the flux-limited kinetic equations governing the condensation/evaporation of $\mathrm{H}_{2} \mathrm{SO}_{4}$ and organic species are integrated, whereas $\mathrm{NH}_{3}$, $\mathrm{HNO}_{3}$, and $\mathrm{HCl}$ are assumed to be in equilibrium (Alvarado, 2008). Aerosol coagulation is calculated using the semiimplicit scheme of Jacobson (2005) with a Brownian coagulation kernel.

\subsection{Gas-phase chemistry updates}

The gas-phase chemistry within the ASP model for Version 2.1 has been completely revised from ASP v1.0, which used the CalTech Atmospheric Chemistry Mechanism (CACM; Griffin et al., 2005). The revised ASP v2.1 gas phase chemical mechanism includes 1608 reactions between 621 species. Examples of the gas-phase species input file and the reaction mechanism input file for ASP v2.1, along with other key chemical input files, are included in the Supplement.

All inorganic gas-phase chemistry within ASP v2.1 was updated to follow the International Union of Pure and Ap- plied Chemistry (IUPAC) recommendations (Atkinson et al., 2004; updated data downloaded from http://iupac.pole-ether. fr/, accessed June 2012). We also tested the Jet Propulsion Laboratory (JPL) recommendations (evaluation no. 17; Sander et al., 2011) for these rate constants, but found that the differences between the recommendations generally made little difference to the model simulations, and as the IUPAC values were closer to those in ASP v1.0, these values were used.

All gas-phase chemistry for organic compounds containing four carbons or less has been "unlumped", i.e., the chemistry for each individual organic compound is explicitly resolved. This was done by following the reactions of the Leeds master chemical mechanism (MCM) v3.2 (http://mcm.leeds. ac.uk/MCM/, accessed June 2012; Jenkin et al., 1997, 2003; Saunders et al., 2003; Bloss et al., 2005) for these species.

The chemical mechanism of isoprene within ASP v2.1 has been updated to follow the Paulot et al. (2009a, b) isoprene scheme, as implemented in GEOS-Chem and including corrections based on more recent studies (e.g., Crounse et al., 2011, 2012). The (lumped) chemistry for all other organic compounds in ASP has been updated to follow the regional atmospheric chemistry mechanism (RACM) v2 (Goliff et al., 2013). We chose RACM 2 over the [California] Statewide Air Pollution Research Center (SAPRC-07) (Carter, 2010) and Carbon Bond (CB05) (Yarwood et al., 2005) lumped chemical mechanisms as the treatment of peroxy radicals in the RACM2 mechanism was more similar to the treatment in the Leeds MCM and the Paulot isoprene scheme, resulting in a more consistent chemical mechanism for ASP v2.1.

Photolysis rates are calculated offline using the tropospheric ultraviolet and visible (TUV) radiation model version 5.0 (Madronich and Flocke, 1998) for $15 \mathrm{~min}$ increments, which are then linearly interpolated in ASP. Alvarado and Prinn (2009) assumed a "clear-sky" radiation field that ignored the effect of aerosol absorption and scattering on the calculated photolysis rates. Here we instead estimate the time-dependent aerosol, $\mathrm{O}_{3}, \mathrm{SO}_{2}$, and $\mathrm{NO}_{2}$ concentrations within the smoke plumes and calculate their effect on the photolysis rates at different heights within the plume. In the TUV simulations, we assume no clouds and that the initial smoke plume AOD at $330 \mathrm{~nm}$ decreases due to dilution assuming a background concentration of $\sim 0$, and the aerosol is assumed to have a constant (both with time and wavelength) single scattering albedo (SSA) of 0.9 based on the review of Aerosol Robotic Network (AERONET) biomass burning smoke optical property retrievals by Reid et al. (2005a). We also dilute the initial plume concentrations of the trace gases $\mathrm{NO}_{2}$ and $\mathrm{SO}_{2}$ assuming a background concentration of $\sim 0$, as these species can also absorb ultraviolet and visible (UVVIS) light and thus can impact photolysis rates. For the photolysis rate calculations only, $\mathrm{O}_{3}$ is assumed to be 0 initially and increased after $15 \mathrm{~min}$ to a constant value based on the observed formation of $\mathrm{O}_{3}$ within the smoke plume. 
Section 5.1 has more details on the specific approach and quantitative values used for the Williams fire.

\subsection{SOA formation updates}

We have updated the SOA formation module to follow the semi-empirical VBS model of Robinson et al. (2007). Our implementation of this scheme followed the approach used by Ahmadov et al. (2012) to link the VBS scheme with the RACM chemical mechanism within WRF-Chem. We use nine surrogates or "bins" for SVOCs as in Dzepina et al. (2009), rather than only four as in Ahmadov et al. (2012). The saturation mass concentration at $300 \mathrm{~K}\left(C^{*}\right.$; see Robinson et al., 2007) of each SVOC bin differs by a factor of 10 , and covers the range from 0.01 to $1.0 \times 10^{6} \mu \mathrm{g} \mathrm{m}^{-3}$. Note that "SVOC" as defined in this paper includes both semi-volatile organic compounds $\left(C^{*}\right.$ between $10^{-2}$ and $10^{3} \mu \mathrm{g} \mathrm{m}^{-3}$ ) and intermediate volatility organic compounds (species with $C^{*}$ between $10^{4}$ and $10^{6} \mu \mathrm{g} \mathrm{m}^{-3}$ ) as defined in Dzepina et al. (2009), but we refer to both of these species classes collectively as "SVOCs" rather than as "S/IVOCs" as in Dzepina et al. (2009) for simplicity. Following the Model to Predict the Multiphase Partitioning of Organics (MPMPO) of Griffin et al. (2003, 2005) and Pun et al. (2002), we assumed that an aqueous phase and a mixed hydrophobic organic phase are always present in the aerosol. Partitioning of organics between the gas and hydrophobic phase is governed by Raoult's law (assuming that all hydrophobic-phase Organic matter (OM) is quasi-liquid and can dissolve organics as in Pankow, 1994a, b), while partitioning of organics into the aqueous phase is governed by Henry's law. Following Pun et al. (2002), we assumed that (1) there is no interaction between the aqueous-phase inorganic ions and the aqueous-phase organics, and thus no organic salt formation, and (2) the activity coefficients of the organic ions (formed by the dissociation of organic acids) are equivalent to those of the corresponding molecular solute. We further assumed that the $\mathrm{pH}$ of the aqueous phase is dominated by the strong inorganic acids and bases, and that the $\mathrm{pH}$ effects of the dissociating organic acids are negligible.

Like most organic compounds, SVOCs will react with $\mathrm{OH}$. Most mechanisms for this chemistry (e.g., Robinson et al., 2007; Dzepina et al., 2009; Grieshop et al., 2009a, b; Ahmadov et al., 2012) parameterize this chemistry by assuming that the SVOCs react with $\mathrm{OH}$ to form a lower volatility SVOC, as in the reaction:

$\mathrm{SVOC}_{i}+\mathrm{OH} \stackrel{k_{\mathrm{OH}}}{\longrightarrow} \mu \mathrm{SVOC}_{i-n}$,

where $\mu$ is the relative mass gain due to oxidation (e.g., via $\mathrm{O}$ addition), $k_{\mathrm{OH}}$ is the reaction rate with $\mathrm{OH}$, and $n$ is the "volatility shift", or by how many factors of 10 to lower the $C^{*}$ of the product with each $\mathrm{OH}$ reaction. This simplified chemistry can be extended to account for the fact that the SVOCs could fragment during oxidation, leading to higher volatility products:

$$
\begin{aligned}
\mathrm{SVOC}_{i} & +\mathrm{OH} \stackrel{k_{\mathrm{OH}}}{\longrightarrow} \mu(1-\alpha) \mathrm{SVOC}_{i-n} \\
& +\mu \alpha \mathrm{SVOC}_{i+1}+\alpha \mathrm{VOC}_{j},
\end{aligned}
$$

where $\alpha$ is the fraction of $\mathrm{SVOC}_{i}$ that fragments into $\mathrm{SVOC}_{i+1}$ and $\mathrm{VOC}_{j}$. Shrivastava et al. (2013) used a similar approach to show that adding SVOC fragmentation to WRFChem simulations of the Mexico City plateau improved the model's ability to simulate the observed concentrations of SOA. However, the highly simplified chemistry of Reactions (R1) or (R2) is not appropriate for situations where reactions with the SVOC compounds are a potentially significant sink of $\mathrm{OH}$, such as in a concentrated smoke plume. Thus, in ASP v2.1, the average, lumped chemistry of the SVOCs is instead parameterized in a more realistic manner for a generic organic species, following the idea of "mechanistic reactivity" (e.g., Carter, 1994; Bowman and Seinfeld, 1994a, b; Seinfeld and Pandis, 1998). After reaction with $\mathrm{OH}$ SVOCs produce peroxy radicals $\left(\mathrm{RO}_{2}\right)$, which can react with $\mathrm{NO}$ to form $\mathrm{NO}_{2}$ and $\mathrm{HO}_{2}$, thereby regenerating $\mathrm{OH}$ and forming $\mathrm{O}_{3}$. Reactions (R3) and (R4) show this more general chemical mechanism for the SVOCs:

$$
\mathrm{SVOC}_{i}+\mathrm{OH} \stackrel{k_{\mathrm{OH}}}{\longrightarrow} \mathrm{RO}_{2, i},
$$

$$
\begin{aligned}
\mathrm{RO}_{2, i} & +\chi \mathrm{NO} \stackrel{k_{\mathrm{OH}}}{\longrightarrow} \mu(1-\alpha) \mathrm{SVOC}_{i-n} \\
& +\mu \alpha \mathrm{SVOC}_{i+1}+\alpha \mathrm{VOC}_{j}+\beta \mathrm{NO}_{2}+\delta \mathrm{HO}_{2},
\end{aligned}
$$

where $k_{\mathrm{RO}_{2, i}}$ is assumed to be $4.0 \times 10^{-12} \mathrm{~cm}^{3}$ molecule ${ }^{-1} \mathrm{~s}^{-1}$ based on the reaction rate for the peroxy radicals from long-chain alkanes and alkenes with NO in RACM2 (Goliff et al., 2013). We can see that $\chi-\beta$ is the number of $\mathrm{NO}_{x}$ lost (implicitly via the addition of a nitrate group to the product SVOCs), $1-\delta$ is the number of $\mathrm{HO}_{x}$ lost, and $\beta+\delta$ is the number of $\mathrm{O}_{3}$ made per reaction (by subsequent reactions of $\mathrm{NO}_{2}$ and $\mathrm{HO}_{2}$ to generate $\mathrm{O}_{3}$ ). For example, the values for long-chain alkanes (HC8) in the $\mathrm{RACM}_{2}$ mechanism (Goliff et al., 2013) would be $\chi=1, \delta=0.63$, and $\beta=0.74$, such that $0.26 \mathrm{NO}_{x}$ and $0.37 \mathrm{HO}_{x}$ are lost and $1.37 \mathrm{O}_{3}$ are formed per reaction. Note that the mechanism of Reactions (R3) and (R4) is still highly simplified: we assume that reaction of SVOC with $\mathrm{OH}$ always produces a $\mathrm{RO}_{2}$ radical, and that the $\mathrm{RO}_{2}$ produced does not react with $\mathrm{HO}_{2}$ or another $\mathrm{RO}_{2}$. Also note that Reactions (R3) and (R4) represent the average chemistry of the unknown species collectively, and may not apply to any individual species in that mixture. Our purpose is less to detail all the possible reactions of the unidentified SVOCs and more to explore how their average chemistry might affect $\mathrm{O}_{3}$ and $\mathrm{OA}$ evolution in smoke plumes. The specific combinations of parameters for Reactions (R3) and (R4) that were evaluated in this study are shown in Table 2. 
We also adjusted the calculation of aerosol water content to use the "kappa" $(\kappa)$ parameterization of organic hygroscopicity (Petters and Kreidenweis, 2007) for the lumped SVOCs. In this parameterization, the hygroscopicity parameter $\kappa$ for the organic species is defined as

$\frac{1}{a_{\mathrm{w}}}=1+\kappa \frac{V_{\mathrm{s}, j}}{V_{\mathrm{w}, i}}$,

where $a_{\mathrm{w}}$ is the activity of water in the solution (equal to the relative humidity $(\mathrm{RH})$ at equilibrium), $V_{\mathrm{s}, i}$ is the volume of the dry organic solute $i$ and $V_{\mathrm{w}, i}$ is the volume of water in the solution. The water content calculated for each organic species, along with that calculated for the inorganic solution ( $V_{\mathrm{w}, \text { inorg }}$; see Sect. 2.1 above) are then combined using the Zdanovskii, Stokes, and Robinson (ZSR) approximation (Zdanovskii, 1948; Stokes and Robinson, 1966):

$$
V_{\mathrm{w}}=\frac{a_{\mathrm{w}}}{1-a_{\mathrm{w}}} \sum_{i} \kappa_{i} V_{\mathrm{s}, j}+V_{\mathrm{w}, \text { inorg }}
$$

\section{ASP photochemistry evaluated with smog chamber data}

To evaluate the performance of the updated photochemical mechanism in ASP v2.1 in predicting the formation of ozone, several test simulations were performed to compare the results of the mechanism to laboratory smog chamber data. This comparison provides us with a baseline for interpreting the results of our simulation of $\mathrm{O}_{3}$ formation in the Williams fire in Sect. 5. The data used for the comparison came from the Environmental Protection Agency (EPA) chamber of Carter et al. (2005), which consists of two collapsible $90 \mathrm{~m}^{3}$ FEP Teflon reactors (chambers A and B).

Table S1 in the Supplement shows the temperature and initial reactant concentrations used in our model to simulate each chamber study. All model simulations were performed at a pressure of $1000 \mathrm{mbar}$, a $\mathrm{RH}$ of $1 \%$, and a $\mathrm{CH}_{4}$ concentration of $1800 \mathrm{ppbv}$. The temperature and concentration data were provided by William P. L. Carter (http://www.cert. ucr.edu/ carter/SAPRC/SAPRCfiles.htm, accessed March 2014). The EPA chamber runs used an eight compound surrogate for ambient VOC concentrations, consisting of formaldehyde $(\mathrm{HCHO})$, ethylene $\left(\mathrm{C}_{2} \mathrm{H}_{4}\right)$, propene, trans-2butene, n-butane, n-octane, toluene, and m-xylene (Carter et al., 1995, 2005). The initial concentrations of HONO were extrapolated from $\mathrm{CO}-\mathrm{NO}_{x}$ and n-butane- $\mathrm{NO}_{x}$ runs to account for the potential chamber radical source (Carter et al., 2005).

Table S2 in the Supplement presents the rates of offgassing (i.e., re-emission of $\mathrm{HCHO}$ and other species from the walls of the reaction chamber), wall reaction rates, and selected photolysis rates for the chamber experiments considered here. The off-gassing rate for HONO was determined as the rate that enabled the SAPRC-99 chemical mechanism

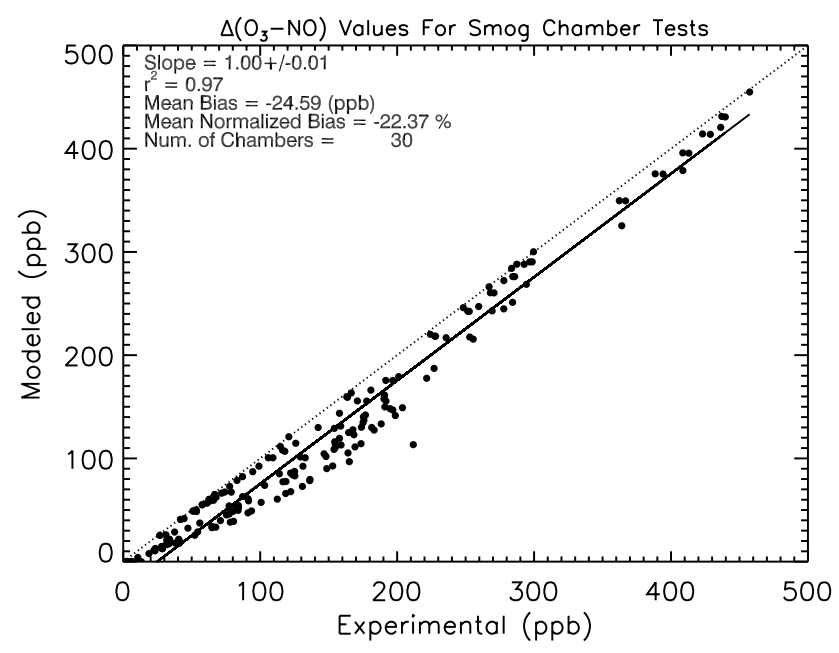

Figure 1. ASP calculated hourly values of $\Delta\left(\left[\mathrm{O}_{3}\right]-[\mathrm{NO}]\right) \equiv\left(\left[\mathrm{O}_{3}\right]_{\text {final }}-[\mathrm{NO}]_{\text {final }}\right)-\left(\left[\mathrm{O}_{3}\right]_{\text {initial }}-[\mathrm{NO}]_{\text {initial }}\right)$ vs. the values measured in the EPA chamber of Carter et al. (2005) for 30 "full surrogate" experiments. Note that all time points for the 30 chamber experiments are plotted, not just the final values.

(Carter, 2000) to best predict the $\mathrm{O}_{3}$ formation observed in $\mathrm{CO}-$, HCHO-, and $\mathrm{CO}-\mathrm{HCHO}-a i r$ experiments performed within the chamber (Carter et al., 2005). The rate in Chamber A was found to be slightly higher than that in Chamber B, so different values are used for the chambers. The off-gassing rate of $\mathrm{HCHO}$ was chosen to match the low but measurable amount of $\mathrm{HCHO}$ found even in pure air and $\mathrm{CO}-\mathrm{NO}_{x}$ experiments in the chamber. Heterogeneous wall loss reaction rates for $\mathrm{O}_{3}, \mathrm{NO}_{2}$, and $\mathrm{N}_{2} \mathrm{O}_{5}$ were also estimated from reactor observations (Carter et al., 2005). The photolysis rate of $\mathrm{NO}_{2}$ in the chambers was measured directly, and scaling factors for the other photolysis rates were calculated by Carter et al. (2005) from the relative spectral intensity of the arc lamp.

Following Carter et al. (2005), we evaluated the ability of our mechanism to simulate the total amount of NO oxidized and $\mathrm{O}_{3}$ formed in the experiments, measured as $\Delta\left(\left[\mathrm{O}_{3}\right]-[\mathrm{NO}]\right)_{\mathrm{t}} \equiv\left(\left[\mathrm{O}_{3}\right]_{\mathrm{t}}-[\mathrm{NO}]_{\mathrm{t}}\right)-\left(\left[\mathrm{O}_{3}\right]_{\text {initial }}-[\mathrm{NO}]_{\text {initial }}\right)$. The hourly results of the comparisons for $\Delta\left(\left[\mathrm{O}_{3}\right]-[\mathrm{NO}]\right)$ are presented in Fig. 1. We can see that the ASP v2.1 mechanism tends to underestimate $\Delta\left(\left[\mathrm{O}_{3}\right]-[\mathrm{NO}]\right)$, with a mean absolute bias of $-24.6 \mathrm{ppbv}$ and a mean normalized bias of $-22.4 \%$. Comparisons of the ASP calculations for $\mathrm{O}_{3}, \mathrm{NO}$, and $\mathrm{NO}_{x}$ (not shown) show that this model underestimate of $\Delta\left(\left[\mathrm{O}_{3}\right]-[\mathrm{NO}]\right)$ is primarily due to the model underestimating $\mathrm{O}_{3}$ formation, rather than underestimating the loss of $\mathrm{NO}$ or $\mathrm{NO}_{x}$. Similarly, the ASP v2.1 calculations for the concentrations of the organic gas species matches well with the chamber measurements (not shown) except for $\mathrm{HCHO}$, where the secondary formation of $\mathrm{HCHO}$ appears to be underestimated. Figure 2 shows the bias in $\Delta\left(\left[\mathrm{O}_{3}\right]-[\mathrm{NO}]\right)$ vs. the initial ratio of the mixing ratio of reactive organic gases (ROGs; e.g., the concentration of the 


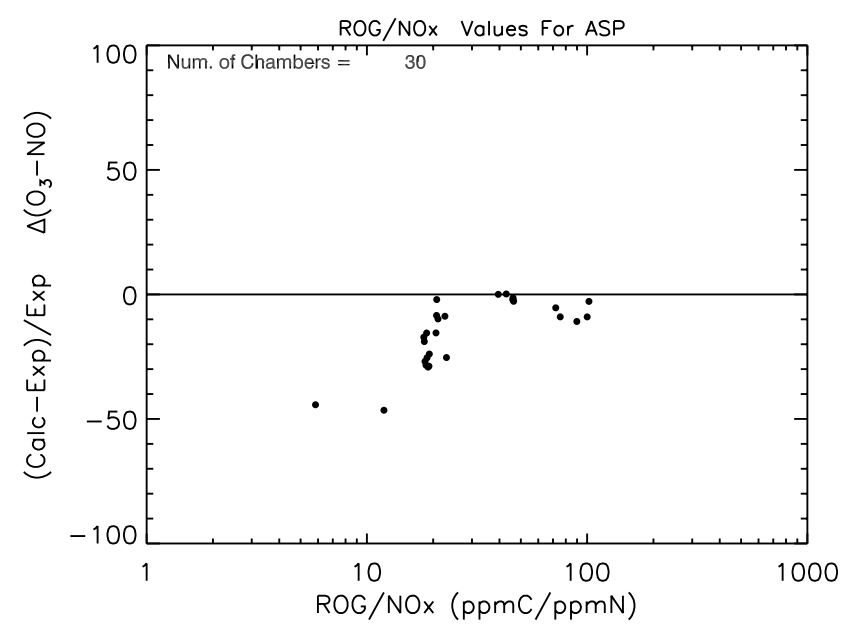

Figure 2. Percentage bias in final $\Delta\left(\left[\mathrm{O}_{3}\right]-[\mathrm{NO}]\right)$ vs. the initial ratio of reactive organic gases $(\mathrm{ROG})$ to $\mathrm{NO}_{x}(\mathrm{ppm} \mathrm{C} / \mathrm{ppm} \mathrm{N}$ ) for the chamber experiments.

surrogate gases in ppm C) to the mixing ratio of $\mathrm{NO}_{x}$ (in $\operatorname{ppm~N)}$. We can see that the bias is between 0 and $-10 \%$ for $\mathrm{ROG} / \mathrm{NO}_{x}$ ratios greater than 30 , but increases to -40 to $-50 \%$ for "high $\mathrm{NO}_{x}$ " cases $\left(\mathrm{ROG} / \mathrm{NO}_{x}\right.$ ratios $\left.<<20\right)$. For comparison, the initial $\mathrm{ROG} / \mathrm{NO}_{x}$ ratio in biomass burning smoke can range from $\sim 10$ to $100 \mathrm{ppm} \mathrm{C} / \mathrm{ppm} \mathrm{N}$ (Akagi et al., 2011; assuming that the total NMOC mass is 1.6 times the mass of carbon in these compounds). Both the general underestimation of $\Delta\left(\left[\mathrm{O}_{3}\right]-[\mathrm{NO}]\right)$ and the increase of the negative bias at low $\mathrm{ROG} / \mathrm{NO}_{x}$ concentrations is consistent with the behaviors of the SAPRC-99 (Carter et al., 2005), SAPRC-07 (Carter, 2010), and CB05 (Yarwood et al., 2005) mechanisms evaluated against the EPA chamber data. Carter (2010) noted that this underprediction of $\mathrm{O}_{3}$ at low $\mathrm{ROG} / \mathrm{NO}_{x}$ ratios was apparently linked to the presence of aromatics in the surrogate mixture, with comparisons of SAPRC-07 with EPA chamber runs with a non-aromatic surrogate mixture showing a positive bias of about $+25 \%$ for cases with low $\mathrm{ROG} / \mathrm{NO}_{x}$ ratios.

\section{Williams fire data}

The Williams fire $\left(34^{\circ} 41^{\prime} 45^{\prime \prime} \mathrm{N}, 120^{\circ} 12^{\prime} 23^{\prime \prime} \mathrm{W}\right)$ was sampled by the US Forest Service (USFS) Twin Otter aircraft from 10:50 to 15:20 LT on 17 November 2009 (Akagi et al., 2012). The fire burned approximately 81 hectares of scrub oak woodland understory and coastal sage scrub. Skies were clear all day and RH was low (11-26\%) with variable winds $\left(2-5 \mathrm{~m} \mathrm{~s}^{-1}\right)$. The Williams fire smoke plume showed significant secondary production of $\mathrm{O}_{3}$ and PAN, but the enhancement ratio of $\mathrm{OA}$ to $\mathrm{CO}_{2}$ decreased slightly downwind (Akagi et al., 2012). In this study, we use the processed data from Akagi et al. (2012) that provided concentrations of several trace gases and OA measured during several quasi-
Lagrangian transects of the Williams fire. Full details on the measurements made and the processing of the data for the plume transects are given in Akagi et al. (2012); those used in this study are briefly described here.

\subsection{Airborne Fourier transform infrared spectrometer}

The University of Montana airborne Fourier transform infrared spectrometer (AFTIR) system and the instruments described below were deployed on a US Forest Service (USFS) Twin Otter aircraft. The AFTIR (Yokelson et al., 1999, 2003) was used to measure 21 gas-phase species, including carbon dioxide $\left(\mathrm{CO}_{2}\right)$, carbon monoxide $(\mathrm{CO})$, nitric oxide $(\mathrm{NO})$, nitrogen dioxide $\left(\mathrm{NO}_{2}\right)$, nitrous acid (HONO), PAN, ozone $\left(\mathrm{O}_{3}\right)$, glycolaldehyde $\left(\mathrm{HCOCH}_{2} \mathrm{OH}\right), \mathrm{C}_{2} \mathrm{H}_{4}, \mathrm{HCHO}$, acetic acid $\left(\mathrm{CH}_{3} \mathrm{COOH}\right)$, and formic acid $(\mathrm{HCOOH})$. IR spectra were collected at $1 \mathrm{~Hz}$. "Grab samples" of air were selected by closing the valves for $1-2 \mathrm{~min}$ to allow signal averaging, and the resulting IR spectra were analyzed to quantify all detectable compounds.

\subsection{Aerosol mass spectrometer}

An Aerodyne compact time-of-flight (CToF) aerosol mass spectrometer (herein referred to as AMS) measured aerosol chemical composition in a repeating cycle for four out of every $12 \mathrm{~s}$ during flight, including within the smoke plume. The AMS has been described in great detail elsewhere (Drewnick et al., 2005; Canagaratna et al., 2007). An isokinetic particle inlet sampling fine particles with a diameter cut-off of a few microns (Yokelson et al., 2007; Wilson et al., 2004) supplied the AMS. As the AMS does not measure super-micron particles, the inlet transmission should not have affected the results. A collection efficiency of 0.5 (Huffman et al., 2005; Drewnick et al., 2003; Allan et al., 2004) was applied to the AMS data, which were processed to retrieve the mass concentration for the major non-refractory particle species: OA, non-sea salt chloride, nitrate, sulfate, and ammonium, with $<36 \%$ uncertainty.

\subsection{Other measurements}

The ambient three-dimensional wind velocity, temperature, $\mathrm{RH}$, and barometric pressure were measured at a frequency of $1 \mathrm{~Hz}$ with a wing-mounted AIMMS-20 probe (Aventech Research, Inc.; Beswick et al., 2008). A non-dispersive infrared instrument (NDIR) (LiCor model 7000) measured $\mathrm{CO}_{2}($ at $0.5 \mathrm{~Hz})$ from the third channel on the isokinetic particle inlet that also supplied the AMS. 


\section{ASP simulation of Williams fire}

\subsection{ASP setup}

As in Alvarado and Prinn (2009), we simulated the Williams fire smoke plume using ASP within a simple Lagrangian parcel model following Mason et al. (2001). We assume a Lagrangian parcel of fixed vertical extent $(H$; here assumed to be $1 \mathrm{~km})$ and down-trajectory length $(L)$, but variable crosstrajectory width $y(t)$. The temperature and pressure of the parcel are assumed to be constant. The full continuity equations for the Lagrangian parcel model are then

$$
\begin{aligned}
\frac{\mathrm{d} C_{q}}{\mathrm{~d} t}= & -\frac{4 K_{y}}{\left(y_{o}^{2}+8 K_{y} t\right)}\left(C_{q}-C_{q}^{\mathrm{a}}\right)-\frac{v_{\mathrm{d}}}{H} C_{q} \\
& +\left(\frac{\mathrm{d} C_{q}}{\mathrm{~d} t}\right)_{\text {cond }}+\left(\frac{\mathrm{d} C_{q}}{\mathrm{~d} t}\right)_{\text {chem }},
\end{aligned}
$$

$$
\begin{aligned}
\frac{\mathrm{d} n_{i}}{\mathrm{~d} t}= & -\frac{4 K_{y}}{\left(y_{o}^{2}+8 K_{y} t\right)}\left(n_{i}-n_{i}^{\mathrm{a}}\right)-\frac{\nu_{\mathrm{d}}}{H} n_{i}+\left(\frac{\mathrm{d} n_{i}}{\mathrm{~d} t}\right)_{\text {cond }}, \\
& +\left(\frac{\mathrm{d} n_{i}}{\mathrm{~d} t}\right)_{\text {chem }}
\end{aligned}
$$

$$
\begin{aligned}
\frac{\mathrm{d} C_{q, i}}{\mathrm{~d} t}= & -\frac{4 K_{y}}{\left(y_{o}^{2}+8 K_{y} t\right)}\left(C_{q, i}-C_{q, i}^{\mathrm{a}}\right)-\frac{\nu_{\mathrm{d}}}{H} C_{q, i} \\
& +\left(\frac{\mathrm{d} C_{q, i}}{\mathrm{~d} t}\right)_{\text {cond }}+\left(\frac{\mathrm{d} C_{q, i}}{\mathrm{~d} t}\right)_{\mathrm{coag}}\left(\frac{\mathrm{d} C_{q, i}}{\mathrm{~d} t}\right)_{\mathrm{chem}},
\end{aligned}
$$

where $C_{q}$ is the concentration of gas-phase species (molecules $\mathrm{cm}^{-3}$ air), $n_{i}$ is the number concentration of particles in size bin $i$ (particles $\mathrm{cm}^{-3}$ air), $c_{q, i}$ is the concentration of aerosol species $q$ in size bin $i\left(\mathrm{~mol} \mathrm{~cm}{ }^{-3}\right.$ air $), y_{o}$ is the initial plume width (m), and $K_{y}$ represents the horizontal diffusivity of the atmosphere $\left(\mathrm{m}^{2} \mathrm{~s}^{-1}\right)$. The superscript a indicates the concentration of the given species in the atmosphere outside of the parcel (i.e., the background concentration).

The first term on the right-hand side of Eqs. (3)-(5) represents the effect of plume dispersion on the concentrations. Note that $y_{o}$ and $K_{y}$ can be reduced to a single parameter, the initial dilution timescale $\tau_{\mathrm{mix}, o}$ :

$-\frac{4 K_{y}}{\left(y_{o}^{2}+8 K_{y} t\right)}=-\frac{1}{\frac{y_{o}^{2}}{4 K_{y}}+2 t}=-\frac{1}{\tau_{\mathrm{mix}, o}+2 t}$.

The second term on the right-hand side of Eqs. (3)-(5) is the effect of deposition on the concentrations, where $v_{\mathrm{d}}$ is the deposition velocity $\left(\mathrm{m} \mathrm{s}^{-1}\right)$. We set the dry deposition velocity equal to 0 for gas-phase species, as the plume did not touch the ground during the modeled period, and use the size-dependent terminal velocity of the aerosol particles as the deposition velocity for aerosol species assuming a $1 \mathrm{~km}$ thick plume. As submicron aerosol dominated the aerosol

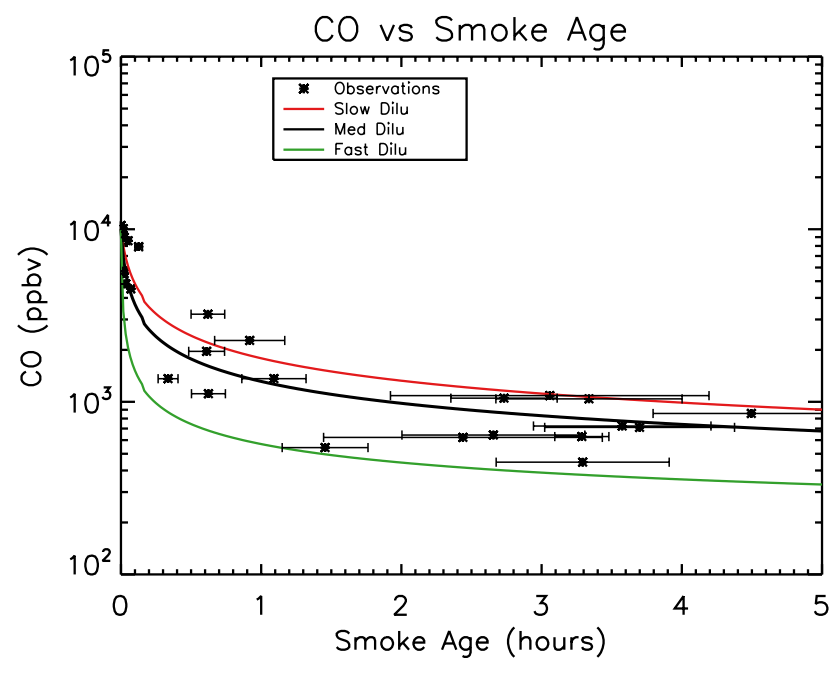

Figure 3. CO mixing ratio (ppbv) vs. smoke age. Red, black, and green are for the slow, best fit (medium), and fast plume dilution rates. Asterisks are the measured mixing ratios, with the horizontal error bars showing the uncertainty in the estimated age, which is much larger than the uncertainty in the $\mathrm{CO}$ mixing ratio.

mass in the smoke plume, this deposition of aerosol species has a negligible effect on the results, and given the low RH during the Williams fire, we also did not include wet deposition of particles or gases. The remaining terms represent the change in gas- and particle-phase concentrations due to net mass transfer between the gas and aerosol phases (cond), coagulation of particles (coag), and chemical production and loss (chem).

The observed changes in $\mathrm{CO}$ mixing ratio were used to determine the best-fit model initial dilution timescale $\left(\tau_{\text {mix }, o}=\right.$ $106.9 \mathrm{~s})$ as well as upper and lower limits of the timescale $\left(\tau_{\text {mix }, o}(0)=15.0\right.$ and $212.2 \mathrm{~s}$, respectively), as shown in Fig. 3. Note that this dilution-fitting procedure neglects the impact of the chemical production and loss of $\mathrm{CO}$ on the observed concentrations, but modeling results with an inert tracer suggest that this error is $<4 \%$, much smaller than the dilution uncertainty represented by our upper and lower limit estimates. The temperature of the plume was set at a constant value of $288.4 \mathrm{~K}$, pressure of $880 \mathrm{hPa}$, and $\mathrm{RH}$ of $15.7 \%$ based on the observations of Akagi et al. (2012). The parcel was assumed to be emitted at 11:00 Pacific standard time (PST) and the model was integrated for $5 \mathrm{~h}$. The integration of the different terms of the continuity Eqs. (3)-(5) were operator split for computational efficiency. The chemistry and mixing time steps were $1 \mathrm{~s}$ for the first 10 min of model integration due to the rapid dilution and chemical changes during this period, and were $60 \mathrm{~s}$ thereafter. The aerosol thermodynamics, condensation, and coagulation time steps were $60 \mathrm{~s}$ throughout.

The initial and background concentrations for the gasphase inorganic and NMOC species are in Table S3 of the 
Table 1. Definition of SVOC species following Grieshop et al. (2009a).

\begin{tabular}{|c|c|c|c|c|c|}
\hline \multirow[t]{2}{*}{ Species } & \multirow{2}{*}{$\begin{array}{r}C^{*} \\
\left(\mu \mathrm{g} \mathrm{m}^{-3} @ 300 \mathrm{~K}\right)\end{array}$} & \multirow{2}{*}{$\begin{array}{r}\Delta H_{\mathrm{vap}} \\
\left(\mathrm{kJ} \mathrm{mol}^{-1}\right)\end{array}$} & \multirow{2}{*}{$\begin{array}{r}\mathrm{MW} \\
\left(\mathrm{g} \mathrm{mol}^{-1}\right)\end{array}$} & \multicolumn{2}{|c|}{ POA volatility distributions ${ }^{\mathrm{a}}$} \\
\hline & & & & Grieshop et al. (2009a) & This study ${ }^{b}$ \\
\hline $\mathrm{SVOC}_{1}$ & $10^{-2}$ & 77 & 524 & 0 & 0 \\
\hline $\mathrm{SVOC}_{2}$ & $10^{-1}$ & 73 & 479 & 0 & 0 \\
\hline $\mathrm{SVOC}_{3}$ & $10^{0}$ & 69 & 434 & 0.1 & 0.038 \\
\hline $\mathrm{SVOC}_{4}$ & $10^{1}$ & 65 & 389 & 0.14 & 0.0532 \\
\hline $\mathrm{SVOC}_{5}$ & $10^{2}$ & 61 & 344 & 0.33 & 0.1254 \\
\hline $\mathrm{SVOC}_{6}$ & $10^{3}$ & 57 & 299 & 0.33 & 0.1254 \\
\hline $\mathrm{SVOC}_{7}$ & $10^{4}$ & 54 & 254 & 0.1 & 0.038 \\
\hline $\mathrm{SVOC}_{8}$ & $10^{5}$ & 50 & 208 & 0 & 0.62 \\
\hline $\mathrm{SVOC}_{9}$ & $10^{6}$ & 46 & 163 & 0 & 0 \\
\hline
\end{tabular}

${ }^{\mathrm{a}}$ Relative mass emissions in each volatility bin. ${ }^{\mathrm{b}}$ Where the relative amounts of $\mathrm{SVOC}_{i}(i=1$ to 7$)$ are kept as in Grieshop et al. (2009a), but additional organic mass is added to $\mathrm{SVOC}_{8}$ to account for the unidentified NMOC mass reported by Akagi et al. (2011).

Table 2. SVOC chemistry parameters in the mechanisms studied here; see Reactions (R3) and (R4) for definitions of the parameters.

\begin{tabular}{lrrrrrrr}
\hline Mechanism & $\begin{array}{c}k_{\mathrm{OH}} \times 10^{11} \\
\left(\mathrm{~cm}^{3} \mathrm{molecule}^{-1} \mathrm{~s}^{-1}\right)\end{array}$ & $\mu$ & $n$ & $\alpha$ & $\chi$ & $\beta$ & $\delta$ \\
\hline Grieshop et al. (2009) & 2.0 & 1.4 & 2 & 0 & 0 & 0 & 0 \\
Robinson et al. (2007) & 4.0 & 1.075 & 1 & 0 & 0 & 0 & 0 \\
Ahmadov et al. (2012) & 1.0 & 1.075 & 1 & 0 & 0 & 0 & 0 \\
Half fragmentation & 1.0 & 1.075 & 1 & .5 & 0 & 0 & 0 \\
Optimized SVOC chemistry & 1.0 & 1.075 & 1 & .5 & 1 & .5 & .6 \\
\hline
\end{tabular}

Supplement, and Table $\mathrm{S} 4$ gives the initial and background concentrations used for the aerosol species. Initial and background concentrations of trace gases and aerosols in the smoke were taken from observations of the Williams fire (Akagi et al., 2012), where available. Emission ratios for other species were calculated using the literature reviews of Akagi et al. (2011) and Andreae and Merlet (2001). Other background concentrations were taken from runs of the GEOS-Chem model (Bey et al., 2001), run for our period as in Fischer et al. (2014).

The volatility distribution for the POA was taken from the wood smoke study of Grieshop et al. (2009a, b). Table 1 shows the POA total mass fractions used for wood smoke in Grieshop et al. (2009a) and the values used in this study for the Williams fire. At the measured temperature $(288.4 \mathrm{~K})$ and initial concentration of organic aerosol in the Williams fire smoke plume $\left(849 \mu \mathrm{g} \mathrm{m}^{-3}\right)$, the Grieshop et al. (2009a) POA volatility distribution implies that $81 \%$ of the total mass of SVOC species $\mathrm{SVOC}_{1}$ to $\mathrm{SVOC}_{7}$ is in the aerosol phase, leaving $200 \mu \mathrm{g} \mathrm{m}^{-3}$ of SVOC species in the gas phase. Note that the May et al. (2013) POA volatility distribution (not shown in Table 1) is more volatile than Grieshop et al. (2009a), with $65 \%$ of the total mass of SVOC species $\mathrm{SVOC}_{1}$ to $\mathrm{SVOC}_{7}$ in the aerosol phase, leaving about $460 \mu \mathrm{g} \mathrm{m}^{-3}$ of SVOC species in the gas phase.
However, Grieshop et al. (2009a) and May et al. (2013) were only able to measure species with a saturation mass concentration $\left(C^{*}\right)$ of $10^{4} \mu \mathrm{g} \mathrm{m}^{-3}$ or less. Furthermore, Akagi et al. (2011) provide emission factors for unidentified NMOCs from savannah/grassland and chaparral fires, with unidentified NMOCs estimated to be equal in mass to the identified species. The savannah/grassland estimate is about twice as large as the chaparral estimate, as fewer species have been identified in chaparral fires. Here we use the savannah/grassland estimate to calculate an emission ratio of $0.195 \mathrm{~g}$ unidentified $\mathrm{NMOC} \mathrm{g}^{-1} \mathrm{CO}$, but assign this value an uncertainty of $\sim 50 \%$, consistent with the lower chaparral estimate. This implies that there is about $2000 \pm 1000 \mu \mathrm{g} \mathrm{m}^{-3}$ of unidentified NMOCs in the gasphase of the smoke. So to be consistent with the EFs of Akagi et al. (2011) and the volatility distributions of Grieshop et al. (2009a) and May et al. (2013), there still needs to be another $1500-1800 \mathrm{\mu g} \mathrm{m}^{-3}$ of unidentified NMOCs initially in the plume with $C^{*}>10^{4} \mu \mathrm{g} \mathrm{m}^{-3}$ which the techniques used by Grieshop et al. (2009) and May et al. (2013) would not have been able to measure. These remaining unidentified NMOCs were included as $\operatorname{SVOC}_{8}\left(C^{*}=10^{5} \mu \mathrm{g} \mathrm{m}{ }^{-3}\right)$, as shown in Table 1 and Tables S3 and S4 in the Supplement. Below we also discuss sensitivity tests that were performed to see how the results change if the remaining uniden- 
tified NMOCs are considered as $\mathrm{SVOC}_{9}\left(C^{*}=10^{6} \mu \mathrm{g} \mathrm{m}{ }^{-3}\right)$ instead, as well as for an increase or decrease of the estimated unidentified SVOC concentrations by $50 \%$.

For all organic species, we assumed a constant $\kappa=0.04$, corresponding to an $\mathrm{O} / \mathrm{C}$ ratio of 0.25 (Jimenez et al., 2009) that is typical of biomass burning organic aerosol (Donahue et al., 2011). Since the RH in the Williams fire plume was very low, this assumption had little impact on our results.

The initial smoke aerosol size distribution was assumed to be a lognormal with a geometric mean diameter $D_{\mathrm{g}}$ of $0.10 \mu \mathrm{m}$ and a standard deviation $(\sigma)$ of 1.9 (unitless) based on Reid and Hobbs (1998) for flaming combustion of Brazilian cerrado, which structurally is a similar mix of shrubs and grasses as in the Williams fire. The initial total number concentration of aerosol particles $\left(2.34 \times 10^{6}\right.$ particles $\left.\mathrm{cm}^{-3}\right)$ was calculated such that the initial total organic aerosol mass matched the $\triangle \mathrm{OA} / \triangle \mathrm{CO}_{2}$ emission ratio from Akagi et al. (2012). The evolution of the aerosol size distribution with time was simulated by ASP v2.1 using a center-moving sectional size distribution with 10 bins, 8 bins for particles with volume-equivalent spherical diameters between 0.05 and $2.0 \mu \mathrm{m}$, one for particles with diameters smaller than $0.05 \mu \mathrm{m}$, and one for particles with diameters greater than $2 \mu \mathrm{m}$.

Photolysis rates were calculated offline using TUV v5.0 (Madronich and Flocke, 1998) as noted in Sect. 2.2 above. The smoke aerosols were assumed to dilute with time according to the three dilution rates derived above (see Fig. 3). In the TUV simulations, we assumed no clouds and an initial AOD of 8.0 at $330 \mathrm{~nm}$ (consistent with the ASP v2.1 calculated initial extinction coefficient and the assumed plume thickness of $1 \mathrm{~km}$ ), which decreases due to dilution assuming a background concentration of $\sim 0$. As noted above, we assumed a constant single scattering albedo of 0.9 based on Reid et al. (2005a). We also assumed initial plume and background concentrations of the trace gases $\mathrm{NO}_{2}$ (initial 295 ppbv, background 0 ppbv) and $\mathrm{SO}_{2}$ (initial $50.9 \mathrm{ppbv}$, background $0 \mathrm{ppbv}$ ). For the photolysis rate calculations only, $\mathrm{O}_{3}$ was assumed to be 0 initially and increased after 15 min to a constant value of $100 \mathrm{ppbv}$ to account for the observed formation of $\mathrm{O}_{3}$ within the smoke plume. The overhead ozone column was assumed to be 278 Dobson units (DU), based on the average of values from the Ozone Monitoring Instrument (OMI) for 16 November 2009 (276 DU) and 18 November 2009 (280 DU) (accessed through Phttp:// jwocky.gsfc.nasa.gov/teacher/ozone_overhead.html on June 2012, now at http://ozoneaq.gsfc.nasa.gov/tools/ozonemap/). The surface albedo was assumed to be 0.035 based on the GEOS-Chem data file for the $0.5^{\circ} \times 0.667^{\circ}$ North American grid for November 1985, which is in turn based on data from the total ozone mapping spectrometer (TOMS). Photolysis rates were calculated for three altitudes: just above the plume (i.e., at $2.1 \mathrm{~km}$ altitude), near the middle of the plume $(1.6 \mathrm{~km})$, and near the bottom of the plume $(1.1 \mathrm{~km})$. This, combined with the three dilution rates, gave nine estimates of

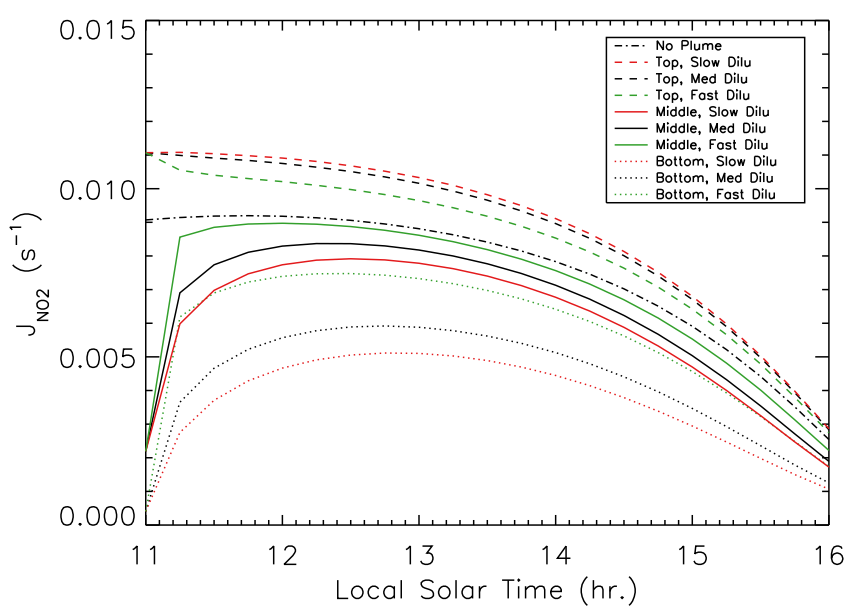

Figure 4. $\mathrm{NO}_{2}$ photolysis rates $\left(\mathrm{s}^{-1}\right)$ vs. local time. Red, black, and green are for the slow, best fit (medium), and fast plume dilution rates. Dashed lines are for photolysis rates above the plume, solid lines are for the middle of the plume, and dotted lines are for the bottom of the plume, as described in the text. The black dot-dashed line is the clear-sky (no plume) photolysis rate.

photolysis rates vs. time. The nine values for the $\mathrm{NO}_{2}$ photolysis rate $\left(J_{\mathrm{NO}_{2}}\right)$ are compared with the clear-sky (no aerosol) case in Fig. 4. In the middle of the plume $(1.6 \mathrm{~km}), J_{\mathrm{NO}_{2}}$ was reduced from an initial clear-sky value of $9 \times 10^{-3} \mathrm{~s}^{-1}$ to an initial value of $2 \times 10^{-3} \mathrm{~s}^{-1}$. However, by $15 \mathrm{~min}$ after emission $J_{\mathrm{NO}_{2}}$ in the middle of the plume increased to 6$8.5 \times 10^{-3} \mathrm{~s}^{-1}$ depending on the dilution rate, showing that the plume reduced photolysis rates by $5-33 \%$ after the initial, rapid dilution of the plume. $J_{\mathrm{NO}_{2}}$ was slightly enhanced above the plume (initially $1.1 \times 10^{-2} \mathrm{~s}^{-1}$ ) over the clear-sky value, and the photolysis rates were lowest in the bottom of the plume. As expected, the impact of the plume was larger for lower dilution rates, but the difference between the different dilution rates was largest for the bottom of the plume. Note that, while our assumption of a constant SSA is questionable as aerosol absorption is likely to change with both smoke age and with wavelength, our use of three dilution rates and three altitudes in the plume results in a wide range of photolysis rates used in this study, which can also account for uncertainties in the aerosol optical properties and other parameters used to calculate the photolysis rates.

\subsection{ASP results with no unidentified SVOC chemistry}

We first ran ASP assuming the unidentified SVOCs emitted by the fire are unreactive. Deficiencies in these simulations provide information on what the average chemistry of the unidentified SVOCs needs to be in order to explain the observations.

Figure 5 shows the ASP v2.1 results and Akagi et al. (2012) observations for the enhancement ratios (EnR; $\mathrm{mol} \mathrm{mol}^{-1}$ ) of $\mathrm{O}_{3}$ and PAN in the Williams fire smoke plume 

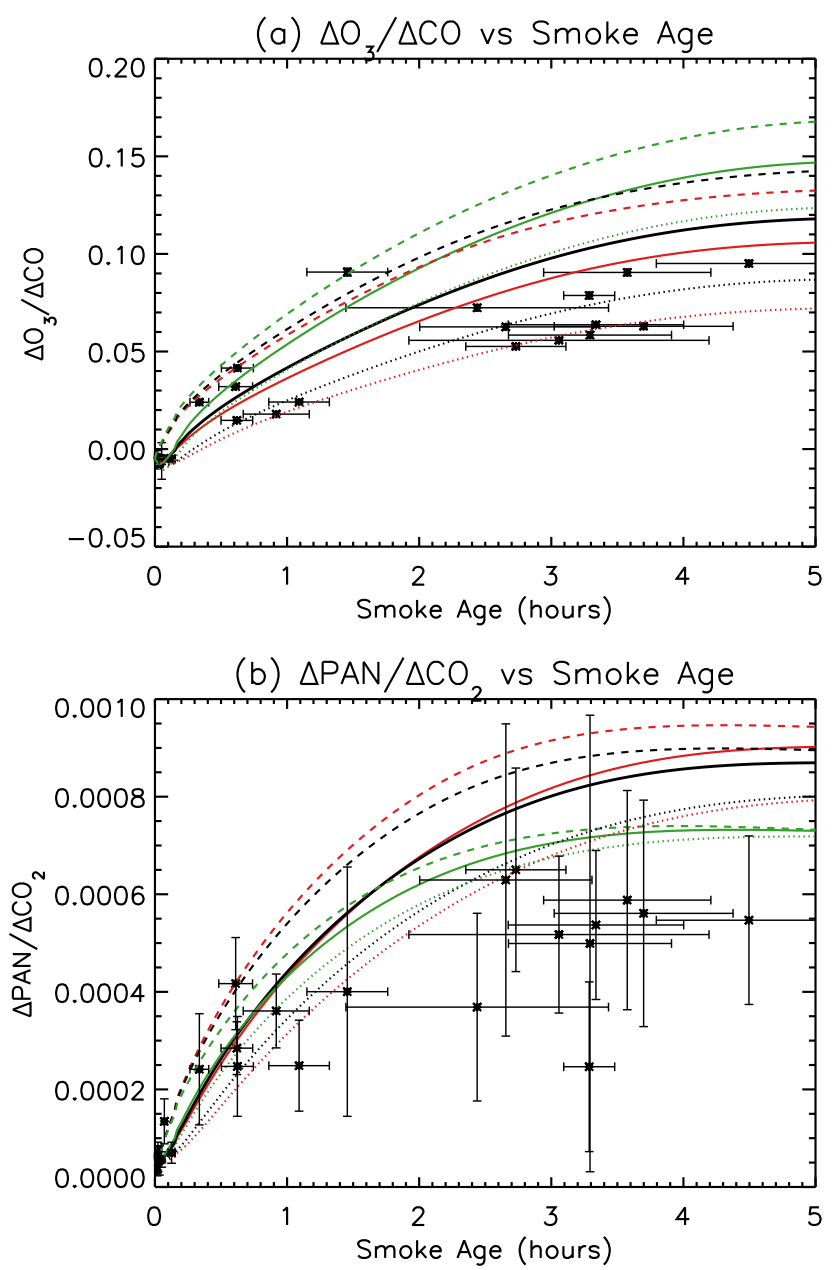

Figure 5. Enhancement ratios $\left(\mathrm{mol} \mathrm{mol}^{-1}\right)$ of (a) $\mathrm{O}_{3}$ to $\mathrm{CO}$ and (b) PAN to $\mathrm{CO}_{2}$ vs. estimated smoke age when the chemistry of the unidentified SVOCs is not included in the model. Asterisks are the measured mixing ratios, with the horizontal error bars showing the uncertainty in the estimated age and the vertical error bars showing the uncertainty in the measurement. Red, black, and green are ASP results for the slow, best fit (medium), and fast plume dilution rates. Dashed lines are for above-plume photolysis rates, while solid lines are for the middle of the plume, and dotted lines are for the bottom of the plume (see the legend in Fig. 4).

vs. time after emissions. The EnR is defined as the ratio of the enhancement of a species $X$ within the smoke plume $\left(\Delta X=C_{x}-C_{x}^{\mathrm{a}}\right.$; Akagi et al., 2011) to the enhancement of a less reactive species, such as $\mathrm{CO}_{2}$ or $\mathrm{CO}$. The choice of whether to use $\mathrm{CO}$ or $\mathrm{CO}_{2}$ in the denominator of the EnR was made on a species-by-species basis to match the choices made in Table 2 of Akagi et al. (2012), which were in turn chosen to minimize the impact of measurement and sampling errors on the EnRs. We can see that the range of dilution rates and photolysis rates simulated for this case capture the general rate of the secondary formation of $\mathrm{O}_{3}$ and PAN, but ASP v2.1 appears to be overestimating the rate of for- mation of these compounds. This is in contrast to Alvarado and Prinn (2009), who found that ASP v1.0 underestimated the much faster $\mathrm{O}_{3}$ formation in the Timbavati savannah fire smoke plume by about $50 \%$.

The ASP v2.1 value for the best estimate dilution and photolysis case (i.e., the best-fit dilution combined with the middle of the plume photolysis rates, plotted as a solid black line in Fig. 5) at $4.5 \mathrm{~h}$ for $\Delta \mathrm{O}_{3} / \Delta \mathrm{CO}$ is $0.116 \mathrm{~mol} \mathrm{~mol}^{-1}$ which is within the uncertainty associated with the average value measured for the Williams fire $(0.095 \pm 0.022)$. This overestimate is similar to the positive bias $(\sim 25 \%)$ of the SAPRC07 mechanism vs. the EPA smog chamber results for low $\mathrm{ROG} / \mathrm{NO}_{x}\left(<20 \mathrm{ppbC} \mathrm{ppb}^{-1} \mathrm{~N}^{-1}\right)$ ratios when aromatics are not part of the surrogate. As aromatics are a minor constituent in biomass burning smoke, and the $\mathrm{ROG} / \mathrm{NO}_{x}$ ratio for savannah/scrubland fires like the Williams fire (without including unidentified species) is $\sim 10 \mathrm{ppb} \mathrm{Cppb}^{-1} \mathrm{~N}^{-1}$, we would expect the mechanism in ASP v2.1 to show a similar positive bias. ASP v2.1 predicts an "average" value of $\triangle \mathrm{PAN} / \triangle \mathrm{CO}_{2}$ of $8.4 \times 10^{-4}$ at $4.5 \mathrm{~h}$ downwind, $65 \%$ larger than the observed value of $(5.10 \pm 1.21) \times 10^{-4}$.

Figure 6 shows the ASP v2.1 results and observations for $\Delta \mathrm{NO}_{x} / \Delta \mathrm{CO}_{2}$ and $\Delta \mathrm{C}_{2} \mathrm{H}_{4} / \Delta \mathrm{CO}$ vs. time after emission. Figure 6a shows that the $\Delta \mathrm{NO}_{x} / \Delta \mathrm{CO}_{2}$ values are correctly simulated by ASP v2.1, with the best estimate dilution and photolysis case EnR of $3.4 \times 10^{-4}$ matching the observed value of $4.6 \pm 2.3 \times 10^{-4} 4$ to $4.5 \mathrm{~h}$ downwind. However, the observations show a faster rate of decay in the first $2 \mathrm{~h}$ after emission than is seen in the model results. Figure $6 \mathrm{~b}$ shows that the decay of $\mathrm{C}_{2} \mathrm{H}_{4}$ is also well matched by the model results, suggesting that the modeled $\mathrm{OH}$ is similar to the actual $\mathrm{OH}$ concentrations. This can also be seen by comparing the modeled $\mathrm{OH}$ concentration for the best estimate dilution and photolysis case $\left(5.3 \times 10^{6}\right.$ molecules $\left.\mathrm{cm}^{-3}\right)$ to that derived by Akagi et al. (2012) using the observed decay of $\mathrm{C}_{2} \mathrm{H}_{4}\left(5.27 \pm 0.97 \times 10^{6}\right.$ molecules $\left.\mathrm{cm}^{-3}\right)$. This is again in contrast with Alvarado and Prinn (2009), who found that ASP underestimated the observed $\mathrm{OH}$ radical concentrations for the Timbavati smoke plume $\left(1.7 \times 10^{7}\right.$ molecules $\mathrm{cm}^{-3}$; Hobbs et al., 2003).

We can explore this contrast further by looking at the rate of loss of HONO in the smoke plume, shown in Fig. 7. Note that unlike the previous figures, Fig. 7 only shows the first hour after emission as the observations showed no detectable HONO further downwind. As noted in Sect. 1, to explain the underestimate of $\mathrm{O}_{3}$ and $\mathrm{OH}$ in the Timbavati fire, Alvarado and Prinn (2009) posited that a heterogeneous reaction of $\mathrm{NO}_{2}$ to make $\mathrm{HONO}$ and $\mathrm{HNO}_{3}$ was taking place in that plume. However, the $\mathrm{O}_{3}$ and $\mathrm{OH}$ results for the Williams fire show no evidence of this chemistry, and the HONO decay seen in Fig. 7 also shows little evidence for a secondary source of HONO except for a few points within the first 12 min after emission that have more HONO than is predicted by the model. While explaining the discrepancy between the Williams and Timbavati results is beyond 

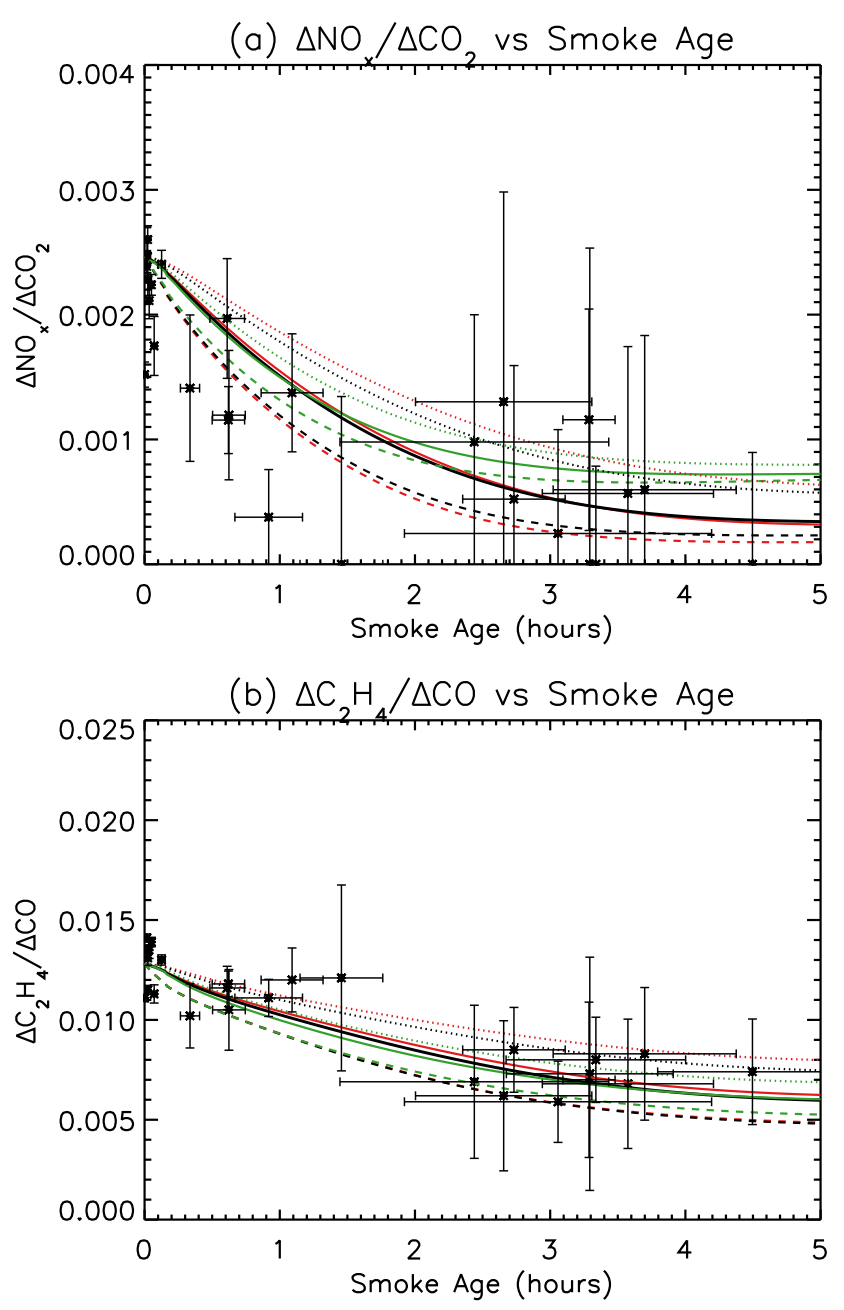

Figure 6. (a) $\mathrm{NO}_{x}$ enhancement ratio (EnR; $\mathrm{mol} \mathrm{mol}^{-1}$ ) to $\mathrm{CO}_{2}$ vs. estimated smoke age when the chemistry of the unidentified SVOCs is not included in the model. (b) EnR of $\mathrm{C}_{2} \mathrm{H}_{4}$ to $\mathrm{CO}$ vs. estimated smoke age. Asterisks are the measured mixing ratios, with the horizontal error bars showing the uncertainty in the estimated age and the vertical error bars showing the uncertainty in the measurement. Red, black, and green are ASP results for the slow, bestfit (medium), and fast plume dilution rates. Dashed lines are for above-plume photolysis rates, while solid lines are for the middle of the plume, and dotted lines are for the bottom of the plume (see the legend in Fig. 4).

the scope of this paper, we note that the Timbavati fire took place closer to the Equator $\left(24^{\circ} \mathrm{S}\right.$ vs. $\left.35^{\circ} \mathrm{N}\right)$, earlier in the year (7 September vs. 17 November) than the Williams fire, and that the RH was higher as well (45.0\% vs. $15.7 \%)$. All of these differences would tend to increase photolysis rates and the formation of $\mathrm{OH}$. In addition, the higher actinic flux and $\mathrm{RH}$ in Timbavati may have increased the speed of reactions for forming $\mathrm{HONO}$ from $\mathrm{NO}_{2}$ that are not included in standard chemical mechanisms, either via aqueous chemistry (Jacob et al., 2000), sunlight-activated humic acid sur-

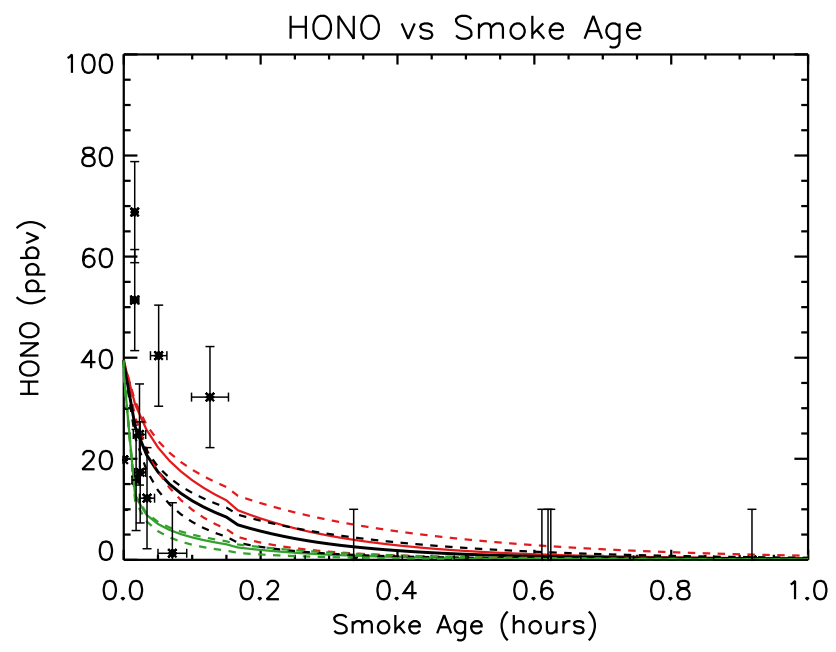

Figure 7. HONO mixing ratio (ppbv) vs. estimated smoke age for the first hour after emission (note difference in $x$ axis scale from Figs. 4-6) when the chemistry of the unidentified SVOCs and a downwind HONO source is not included in the model. Asterisks are the measured mixing ratios, with the horizontal error bars showing the uncertainty in the estimated age and the vertical error bars showing the uncertainty in the measurement. Red, black, and green are ASP results for the slow, best fit (medium), and fast plume dilution rates. Dashed lines are for above-plume photolysis rates, while solid lines are for the middle of the plume, and dotted lines are for the bottom of the plume (see the legend in Fig. 4).

faces (Stemmler et al., 2006, 2007), or photo-excited $\mathrm{NO}_{2}$ reacting with $\mathrm{H}_{2} \mathrm{O}$ (Ensberg et al., 2010). Though we find no evidence for secondary HONO production in the Williams fire data, this does not preclude that some HONO was made, but remained below the AFTIR detection limit of $10 \mathrm{ppbv}$ as the plume diluted.

Figure 8 shows the ASP results for two aldehydes, $\mathrm{HCHO}$ and glycoaldehyde $\left(\mathrm{HCOCH}_{2} \mathrm{OH}\right)$, and two organic acids, $\mathrm{HCOOH}$ and $\mathrm{CH}_{3} \mathrm{COOH}$, in the Williams fire plume in terms of EnRs to CO. We can see that ASP generally underestimates the formation of these species. Part of this underestimate may be due to errors in the chemical mechanism for known precursor compounds, as was seen for $\mathrm{HCHO}$ in the smog chamber results, but neglecting the chemistry of the SVOCs and their ability to form these smaller organic compounds is also likely responsible for this underestimate.

Figure 9 shows the modeled OA enhancement ratios $\left(\triangle \mathrm{OA} / \Delta \mathrm{CO}_{2}, \mathrm{~g} \mathrm{~g}^{-1}\right)$ at $4.5 \mathrm{~h}$ downwind using the parameters listed in Table 2 in addition to the observed average OA enhancement ratio $\left(2.83 \pm 1.08 \times 10^{-3}\right)$ and the modeled OA enhancement ratio for the case where the chemistry of the unidentified SVOCs is not included $\left(2.27 \times 10^{-3}\right)$. When SVOC chemistry was not included, some of the original OA evaporated into the gas phase as the plume diluted, and as there was no chemistry to make these SVOC species less volatile, they stayed in the gas phase leading to a net de- 

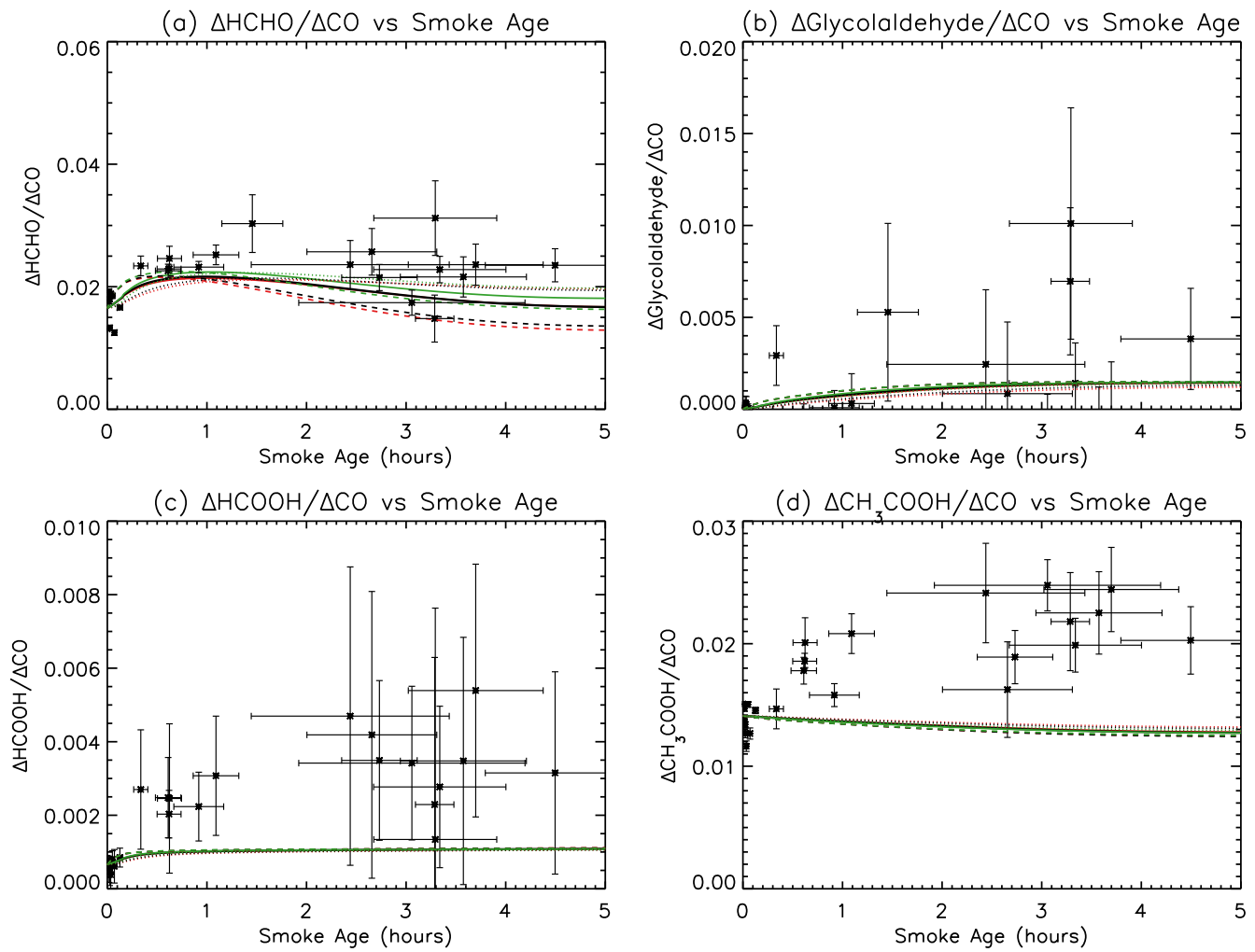

Figure 8. Enhancement ratio $\left(\mathrm{EnR} ; \mathrm{mol} \mathrm{mol}^{-1}\right)$ of (a) $\mathrm{HCHO},(\mathbf{b})$ glycoaldehyde $\left(\mathrm{HCOCH}_{2} \mathrm{OH}\right)$, (c) formic acid $(\mathrm{HCOOH})$, and $(\mathbf{d})$ acetic acid $\left(\mathrm{CH}_{3} \mathrm{COOH}\right)$ to $\mathrm{CO}$ vs. estimated smoke age when the chemistry of the unidentified SVOCs is not included in the model. Asterisks are the measured mixing ratios, with the horizontal error bars showing the uncertainty in the estimated age and the vertical error bars showing the uncertainty in the measurement. Red, black, and green are ASP results for the slow, best fit (medium), and fast plume dilution rates. Dashed lines are for above-plume photolysis rates, while solid lines are for the in-plume rates, as described in the text.

crease in $\triangle \mathrm{OA} / \triangle \mathrm{CO}_{2}$ with time. Changing the gas-phase concentrations of the unidentified SVOC by $\pm 50 \%$ has a small impact $(\sim 3 \%)$ on these results, but the match between the model and observation could be improved by using a less volatile POA distribution than that given by Grieshop et al. (2009a). However, the modeled decrease without SVOC chemistry is larger (but still within the error bars) than the decrease that was reported by Akagi et al. (2012). In addition, the assumption that the SVOCs do not react is unrealistic - as large multi-functional organic compounds, they should have a relatively fast reaction rate with $\mathrm{OH}$ (see Sect. 5.3 below). Thus, in Sect. 5.3 through 5.5 we test different, more realistic implementations for the chemistry of these SVOCs.

\subsection{OH reaction rate and fragmentation probability of the unidentified SVOCs}

Here we evaluate the ability of the parameters from the original VBS paper of Robinson et al. (2007), a study of SOA formation in wood smoke by Grieshop et al. (2009a, b), and the implementation of the VBS scheme into WRFChem by Ahmadov et al. (2012) to simulate the observed evolution of $\mathrm{OA}$ in the Williams fire plume. Table 2 shows

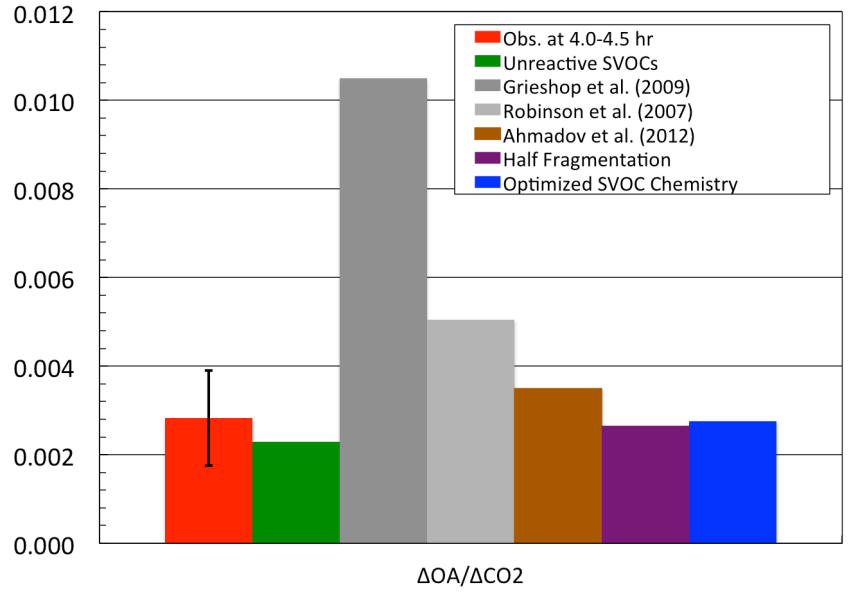

Figure 9. Enhancement ratio (EnR; $\left.\mathrm{g} \mathrm{g}^{-1}\right)$ of organic aerosol (OA) to $\mathrm{CO}_{2}$ after 4 to $4.5 \mathrm{~h}$ of smoke aging. The error bars on the observed values are based on the $36 \%$ uncertainty in the AMS observations of OA. All model results assume the best-estimate dilution rate and the photolysis rates corresponding to the middle of the plume (solid black line in Fig. 4). 
the values for the parameters in Reactions (R3) and (R4) that define these various SVOC mechanisms. Figure 9 shows that the SVOC mechanisms of Robinson et al. (2007) and Grieshop et al. (2009a, b) overestimated the OA downwind by a factor of 1.8 and 3.7 , respectively. This is primarily due to their relatively large values for $k_{\mathrm{OH}}$. For the Grieshop et al. (2009a, b) case, the overestimation is also partially due to the large increase in mass $(\mu)$ and decrease in volatility $(n)$ for each $\mathrm{OH}$ reaction. The OA formed using these mechanisms can be reduced by a further $25 \%$ if we assume the unidentified SVOCs are mainly the more volatile $\mathrm{SVOC}_{9}\left(C^{*}=10^{6} \mu \mathrm{g} \mathrm{m}^{-3}\right)$ instead of $\mathrm{SVOC}_{8}\left(C^{*}=10^{5} \mu \mathrm{g} \mathrm{m}^{-3}\right)$, but are fairly insensitive to errors in the POA volatility distribution. The scheme of Ahmadov et al. (2012), with $k_{\mathrm{OH}}=10^{-11} \mathrm{~cm}^{3}$ molecule ${ }^{-1} \mathrm{~s}^{-1}$, was consistent with the uncertainty in the observations, but slightly higher than the observed value $\left(3.48 \times 10^{-3}\right.$ vs. the observed value of $2.83 \pm 1.08 \times 10^{-3}$ ). One approach to further reduce the modeled OA would be to reduce $k_{\mathrm{OH}}$ even further. However, it seems unlikely that the average $\mathrm{OH}$ reaction rate of the unidentified SVOC species would be less than $10^{-11} \mathrm{~cm}^{3}$ molecule ${ }^{-1} \mathrm{~s}^{-1}$, as this is close to the reaction rate for large alkanes $\left(k_{\mathrm{OH}}(298 \mathrm{~K})=1.1 \times 10^{-11} \mathrm{~cm}^{3}\right.$ molecule ${ }^{-1} \mathrm{~s}^{-1}$; Goliff et al., 2013) and the presence of other functional groups (double bonds, aldehydes) would be expected to result in even higher reaction rates. For example, $\alpha$-pinene has a $k_{\mathrm{OH}}(298 \mathrm{~K})$ of $5.0 \times 10^{-11} \mathrm{~cm}^{3}$ molecule ${ }^{-1} \mathrm{~s}^{-1}$ (Goliff et al., 2013), and other monoterpenes can have even faster reaction rates with $\mathrm{OH}$. Thus, we think a more likely explanation for the remaining overestimate is that a substantial fraction of the SVOC and $\mathrm{OH}$ reactions resulted in the fragmentation of the primary SVOC into more volatile compounds, as in the 2D-VBS schemes of Jimenez et al. (2009) and Donahue et al. (2011).

Figure 9 shows that a $k_{\mathrm{OH}}$ of $10^{-11} \mathrm{~cm}^{3}$ molecule ${ }^{-1} \mathrm{~s}^{-1}$ and a fragmentation probability of $50 \%$ (the "half fragmentation" case; see Table 2) provided a reasonably good match with the observed $\Delta \mathrm{OA} / \Delta \mathrm{CO}_{2} 4.5 \mathrm{~h}$ downwind in the smoke plume $\left(2.63 \times 10^{-3}\right.$ vs. the observed value of $\left.2.83 \pm 1.02 \times 10^{-3}\right)$. Here we assumed that the SVOC fragmented into a small VOC and another, more volatile, SVOC, as in Reactions (R3) and (R4). While this is a relatively large fragmentation probability, we note that it seems reasonable given the likely complex and multifunctional nature of the unidentified SVOCs in a biomass burning smoke plume.

This fragmentation of the SVOCs after reaction with $\mathrm{OH}$ could also help to explain the underestimate of aldehydes and organic acids seen in Sect. 5.2 when SVOC chemistry was neglected. For example, Fig. 10 shows the ASP modeled EnR of $\mathrm{CH}_{3} \mathrm{COOH}$ when we assumed that the VOC fragment produced in Reaction (R4) is $\mathrm{CH}_{3} \mathrm{COOH}$. This provided a remarkably good match with the observed $\mathrm{CH}_{3} \mathrm{COOH}$ formation, providing additional evidence to support the fragmentation hypothesis. While we are not claiming to have proven this is the source of the missing $\mathrm{CH}_{3} \mathrm{COOH}$, we note

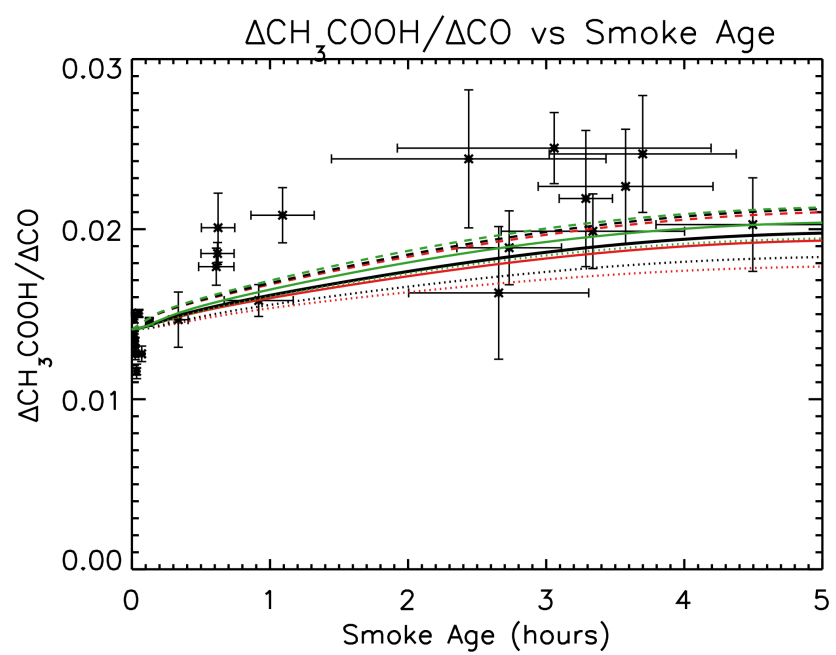

Figure 10. As in Fig. 8d, but for the "half fragmentation" SVOC mechanism (see Table 1) where the VOC fragment produced by fragmentation of the parent SVOC is assumed to become acetic acid $\left(\mathrm{CH}_{3} \mathrm{COOH}\right)$.

that the fragmentation hypothesis is thus consistent with the initial underestimate of the secondary formation of aldehydes and organic acids in ASP v2.1. In addition, there is some evidence from biomass burning plume observations that the formation of $\mathrm{CH}_{3} \mathrm{COOH}$ and $\mathrm{OA}$ are inversely correlated with each other. In the Yucatan plume studied by Yokelson et al. (2009), a large amount of SOA was formed, but $\mathrm{CH}_{3} \mathrm{COOH}$ did not increase downwind, while in the Williams fire, $\mathrm{CH}_{3} \mathrm{COOH}$ increased, but $\mathrm{OA}$ did not. Thus, the limited amount of relevant airborne data in BB plumes is so far consistent with the idea that the branching between functionalization and fragmentation in BB plumes is variable and future work should identify what environmental and combustion factors control the outcome.

An additional potential explanation for the SOA overestimate observed when the schemes of the Robinson et al. (2007), Grieshop et al. (2009a, b), and Ahmadov et al. (2012) were used is that the OA was becoming more viscous and "glassy" with time (i.e., the particles had a lower bulk diffusivity), thereby reducing the amount of quasi-liquid OA for SVOC compounds to dissolve into (e.g., Kidd et al., 2014; Zaveri et al., 2014). There has been some recent evidence for this process occurring in smoke plumes from biomass burning in the western USA (A. Sedlacek, personal communication, March 2014). ASP v2.1 is not able to examine this possibility in detail, but we do note that while the formation of "glassy" OA would reduce SOA formation, it likely would not increase the formation of aldehydes or organic acids as in the fragmentation hypothesis. 


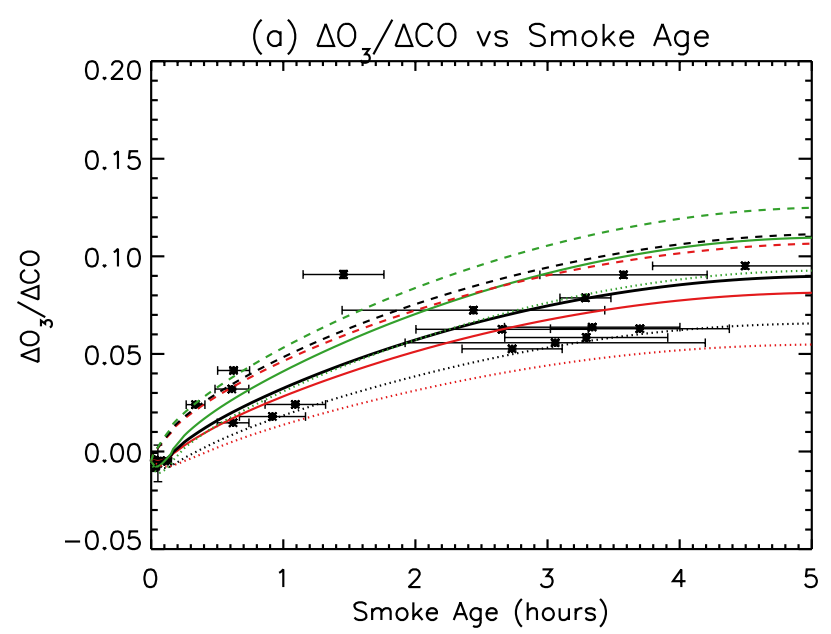

(b) $\triangle \mathrm{PAN} / \triangle \mathrm{CO}$, vs Smoke Age

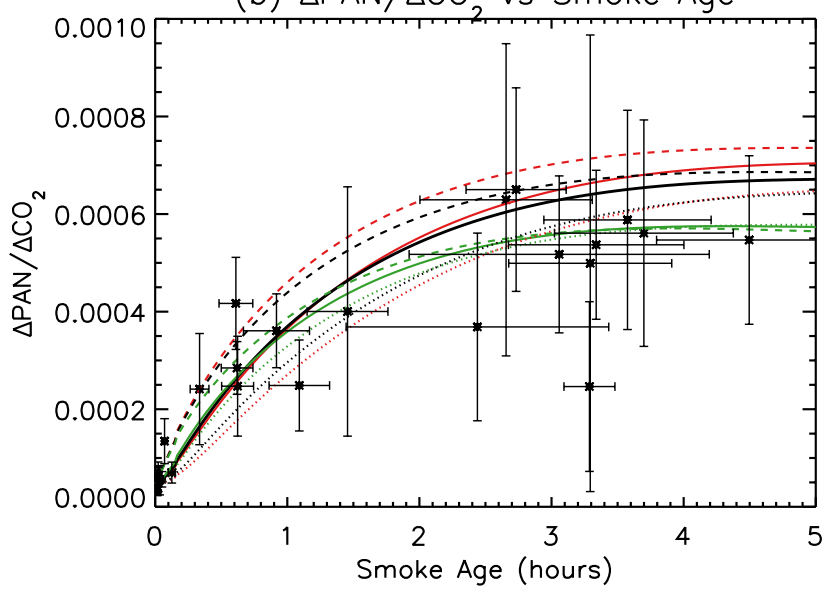

Figure 11. As in Fig. 5, but for the "half fragmentation" SVOC mechanism rather than no fragmentation (see Table 2).

\section{4 $\mathrm{HO}_{x}$ and $\mathrm{NO}_{x}$ chemistry of the unidentified SVOCs}

Section 5.3 showed that an SVOC mechanism following Reaction (R2) with a $k_{\mathrm{OH}}$ of $10^{-11} \mathrm{~cm}^{3}$ molecule ${ }^{-1} \mathrm{~s}^{-1}$ and a fragmentation probability $\alpha$ of up to 0.5 (the "half fragmentation" scheme in Table 2) could explain the observed evolution of OA in the Williams fire. However, neglecting the regeneration of $\mathrm{HO}_{x}$ and reaction of the peroxy radical with $\mathrm{NO}$, as in Reaction R2, can lead to substantial underestimates of $\mathrm{OH}$ in the concentrated smoke plumes. This is because including Reaction (R2) in ASP leads to a loss of $\mathrm{OH}$ with no corresponding regeneration of $\mathrm{HO}_{2}$.

For example, Fig. 11 shows that using the "half fragmentation" scheme reduced the ASP v2.1 estimates of the enhancement ratios of $\mathrm{O}_{3}$ and PAN downwind by 24 and $23 \%$, respectively (for the best estimate dilution and photolysis case, the black line in Fig. 5), while Fig. 12 shows that it increased the ASP v2.1 estimates of $\mathrm{C}_{2} \mathrm{H}_{4}$ and $\mathrm{NO}_{x}$ downwind by 33 and $151 \%$, respectively. The "half fragmentation" $\mathrm{O}_{3}$ and PAN estimates are more consistent with the observations -
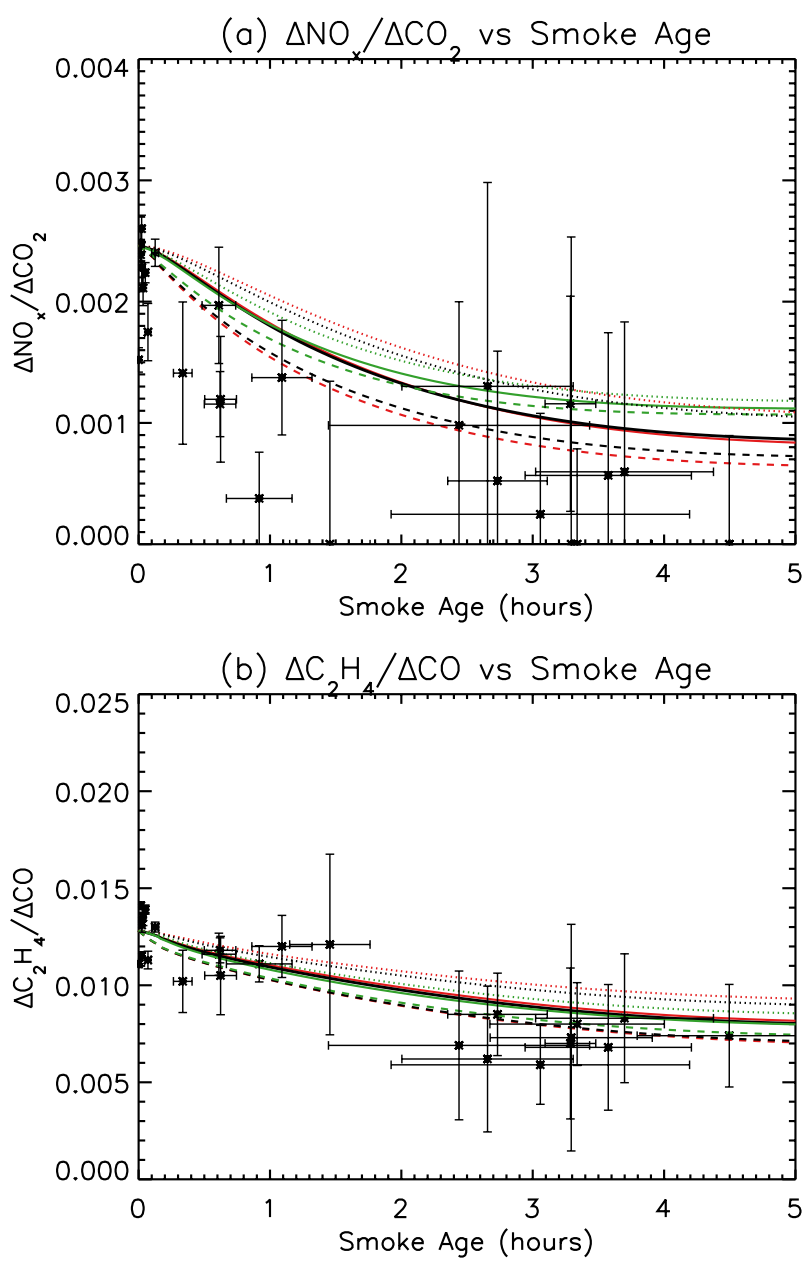

Figure 12. As in Fig. 6, but for the "half fragmentation" SVOC mechanism (see Table 2).

the overestimate of PAN seen with the unidentified SVOC chemistry neglected in Sect. 5.2 has disappeared - but the large overestimate of $\mathrm{NO}_{x}$ (i.e., underestimate of $\mathrm{NO}_{x}$ loss in the plume presumably due to missing organic nitrogen formation) is a serious problem. While this underestimate of $\mathrm{NO}_{x}$ loss reduces the amount of $\mathrm{O}_{3}$ and PAN formed within $5 \mathrm{~h}$ after emission, it would lead to large overestimates of the impact of biomass burning plumes on $\mathrm{O}_{3}$ and PAN formation further downwind.

In addition, the chemistry of Reaction (R2) is unrealistic, in that it implies a total loss of $\mathrm{OH}$ and no effect of the SVOC oxidation on $\mathrm{NO}_{x}$. One approach for addressing the first concern is to artificially regenerate the $\mathrm{OH}$ by simply adding it as an additional product to Reaction (R2). While this makes sense as a "first do no harm" modeling approach to keep the gas-phase results the same regardless of the SVOC scheme, it is equally unrealistic, as it assumes that the SVOCs are oxidized without having any impact on $\mathrm{NO}_{x}$ or $\mathrm{HO}_{x}$.

We prefer to approach this problem by recognizing that SVOCs are going to have impacts on the $\mathrm{HO}_{x}$ and $\mathrm{NO}_{x}$ rad- 
ical budgets just like any other organic species, and that this chemistry can be approximated via Reactions (R3) and (R4). Including this more realistic, yet still simplified, chemistry allows ASP to simultaneously simulate the observed changes in $\mathrm{OA}$ and $\mathrm{O}_{3}$ while still making reasonable, chemically plausible assumptions about the chemistry of the unidentified SVOCs emitted by the fire.

Our approach thus used the observations of $\mathrm{OA}, \mathrm{O}_{3}, \mathrm{PAN}$, $\mathrm{NO}_{x}$, and $\mathrm{C}_{2} \mathrm{H}_{4}$ in the Williams fire as constraints on $\beta$ and $\delta$, the amount of $\mathrm{NO}_{2}$ and $\mathrm{HO}_{2}$ produced in Reaction ( $\left.\mathrm{R} 4\right)$, respectively, while assuming that $\chi=1$ throughout. For the Williams fire, we know from the above results that we want the optimized SVOC chemistry to (a) increase $\mathrm{O}_{3}, \mathrm{PAN}$, and OA formation as little as possible; (b) increase the loss of $\mathrm{NO}_{x}$, either through organic nitrate formation or increased $\mathrm{OH}$ concentrations; and (c) increase the $\mathrm{OH}$ concentration, thereby increasing $\mathrm{C}_{2} \mathrm{H}_{4}$ loss. We found that using the parameters for large alkanes from $\operatorname{RACM} 2(\delta=0.63$ and $\beta=$ $0.74)$ generally produced too much $\mathrm{O}_{3}$ and PAN and too little $\mathrm{OH}$, but did a reasonable job for $\mathrm{NO}_{x}$ loss. However, attempts to increase $\mathrm{OH}$ by increasing $\delta$ led to too much $\mathrm{O}_{3}$ formation except for unrealistically low values of $\beta(\sim 0.1)$. Thus, we set $\delta=0.6$ and reduced $\beta$ to 0.5 , implying that 1.1 $\mathrm{O}_{3}$ is formed per molecule of SVOC reacted. These parameters (arrived at by trial and error) appear to give the best balance of reducing modeled $\mathrm{NO}_{x}$ and $\mathrm{C}_{2} \mathrm{H}_{4}$ mixing ratios while minimizing the increase in $\mathrm{O}_{3}$, PAN, and OA. The following section discusses the ASP v2.1 model results for the Williams fire smoke plume using these parameters in detail. Note that while slightly different, more precise parameters might provide a slightly better match with observation, our goal here is not to derive exact best-fit parameters, but rather to roughly classify the average chemistry of the SVOCs in the Williams fire smoke plume, both for modeling this fire and for future comparisons with other smoke plumes.

\subsection{Results with optimized SVOC chemistry}

Figure 9 shows the $\Delta \mathrm{OA} / \Delta \mathrm{CO}_{2} 4.5 \mathrm{~h}$ downwind in the smoke plume using the optimized SVOC chemistry discussed in Sect. 5.4. For the best estimate dilution and photolysis model case (i.e., the solid black line in Fig. 5), $\Delta \mathrm{OA} / \Delta \mathrm{CO}_{2}$ is $2.75 \times 10^{-3}\left(\mathrm{~g} \mathrm{~g}^{-1}\right)$, very close to the observed value of $2.83 \pm 1.02 \times 10^{-3}$. As in Section 5.2, changing the gas-phase concentrations of the unidentified SVOC by $\pm 50 \%$ has a small impact $(\sim 3 \%)$ on these results, as does assuming that the unidentified SVOCs are mainly the more volatile $\mathrm{SVOC}_{9}\left(C^{*}=10^{6} \mu \mathrm{g} \mathrm{m}^{-3}\right)$ instead of $\mathrm{SVOC}_{8}$ $\left(C^{*}=10^{5} \mu \mathrm{g} \mathrm{m}^{-3}\right)$. However, this result is still sensitive to the POA volatility distribution - for example, moving all the mass in $\mathrm{SVOC}_{3}\left(C^{*}=1 \mu \mathrm{g} \mathrm{m}^{-3}\right)$ to $\operatorname{SVOC}_{7}\left(C^{*}=\right.$ $10^{4} \mu \mathrm{g} \mathrm{m}^{-3}$ ) decreases the modeled $\triangle \mathrm{OA} / \Delta \mathrm{CO}_{2}$ downwind by $12 \%$ for this case.

Figure 13 shows the enhancement ratios of $\mathrm{O}_{3}$ and PAN for the optimized SVOC chemistry, and Fig. 14 shows the
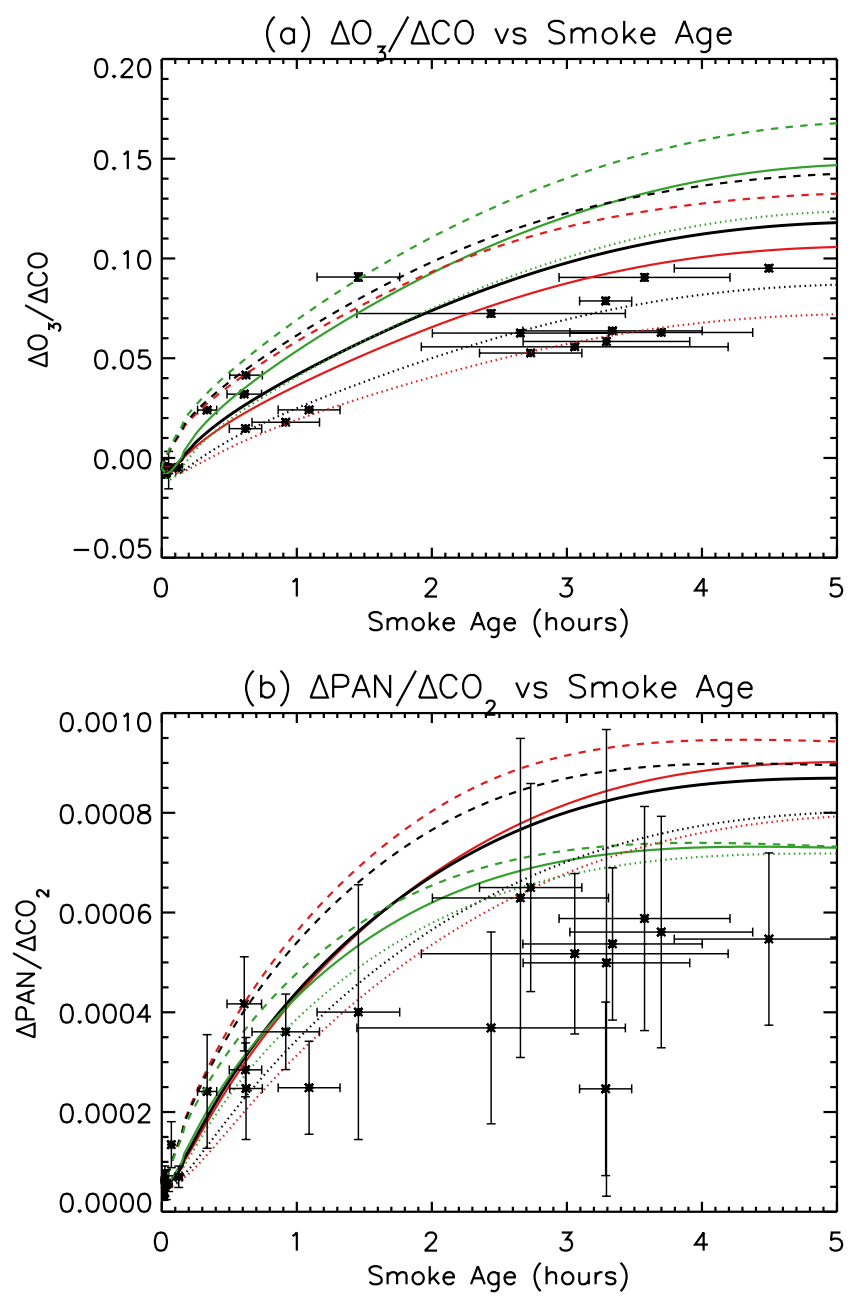

Figure 13. As in Fig. 5, but for the optimized SVOC chemistry (see Table 2).

results for $\mathrm{NO}_{x}$ and $\mathrm{C}_{2} \mathrm{H}_{4}$. The $\mathrm{O}_{3}$ results are very similar to those from Sect. 5.2 (where SVOC chemistry was not included in the model), while the PAN results are slightly lower (and closer to the observed values) than in that case. For the best estimate dilution and photolysis model case $\Delta \mathrm{O}_{3} / \Delta \mathrm{CO}$ is 0.119 at $4.5 \mathrm{~h}$ downwind, about $25 \%$ larger than the observed value of $0.095 \pm 0.022$, while the $\triangle \mathrm{PAN} / \Delta \mathrm{CO}_{2}$ is now $7.56 \times 10^{-4}$ at $4.5 \mathrm{~h}$ downwind, about $48 \%$ larger than the observed value of $(5.10 \pm 1.21) \times 10^{-4}$. However, the $\mathrm{O}_{3}$ and PAN values are reasonably close given the uncertainties in the concentrations and in the estimated smoke ages for the observations.

The $\mathrm{NO}_{x}$ results were much improved from the "halffrag" case in Sect. 5.4, with the best estimate dilution and photolysis case $\Delta \mathrm{NO}_{x} / \Delta \mathrm{CO}_{2}$ of $1.6 \times 10^{-4}$ being below the mean observed value of $4.6 \pm 2.3 \times 10^{-4}$, but consistent with the error bars of the individual samples as shown in Fig. 14. We could attempt to get a closer match by increasing $\beta$, but at the cost of increases in the modeled $\mathrm{O}_{3}$, 

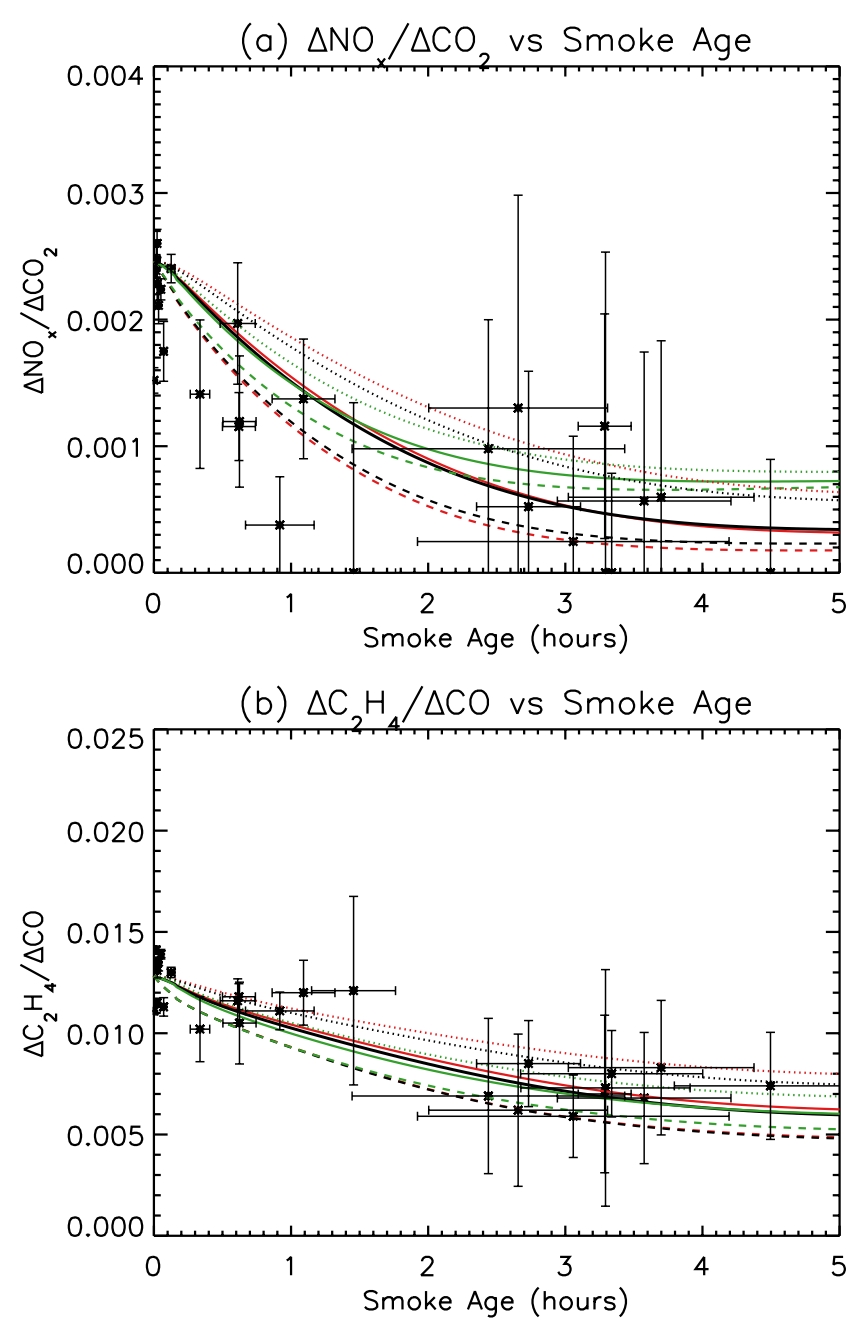

Figure 14. As in Fig. 6, but for the optimized SVOC chemistry (see Table 2).

PAN, and OA formation. The decay of $\mathrm{C}_{2} \mathrm{H}_{4}$ is also better modeled than in the half fragmentation case, suggesting the model $\mathrm{OH}$ is also improved. The modeled $\mathrm{OH}$ concentration for the best estimate dilution and photolysis case is now $5.3 \times 10^{6}$ molecules $\mathrm{cm}^{-3}$, matching the observed value of $5.27 \pm 0.97 \times 10^{6}$ molecules $\mathrm{cm}^{-3}$.

\section{Conclusions}

We have used version 2.1 of the ASP model, which includes extensive updates to the gas-phase chemistry and SOA formation modules, to simulate the near-source chemistry within the smoke plume from the Williams fire, as sampled by Akagi et al. (2012). We find that the assumptions made about the chemistry of the unidentified SVOCs emitted by the fire have a large impact on the simulated secondary formation of $\mathrm{O}_{3}$, PAN, and $\mathrm{OA}$ within the plume. We showed that reasonable assumptions about the chemistry of the unidentified
SVOCs can successfully simulate the observations within the uncertainties of the measurements, the estimated smoke ages of the samples, the plume dilution rate, and the vertical location of the samples in the plume. For the Williams fire, these assumptions were (1) a reaction rate constant with $\mathrm{OH}$ of $\sim 10^{-11} \mathrm{~cm}^{3} \mathrm{~s}^{-1}$; (2) a significant fraction (up to $\sim 50 \%$ ) of the $\mathrm{RO}_{2}+\mathrm{NO}$ reaction resulted in fragmentation, rather than functionalization; (3) $\sim 1.1$ molecules of $\mathrm{O}_{3}$ were formed for every molecule of SVOC that reacts; and (4) $60 \%$ of the $\mathrm{OH}$ that reacted with the SVOC was regenerated as $\mathrm{HO}_{2}$ by the $\mathrm{RO}_{2}+\mathrm{NO}$ reaction, which implied (5) that $50 \%$ of the NO that reacted with the SVOC peroxy radicals was lost, likely due to organic nitrate formation. However, this chemistry still overestimates PAN formation downwind by about $50 \%$, suggesting the need for further refinements to the chemistry and estimated emission rates of PAN precursors like acetaldehyde. Furthermore, these specific, quantitative results only apply to the Williams fire analyzed in this paper. Further analysis of other smoke plume observations is needed to determine how these parameters vary between individual smoke plumes.

The method used in this study can provide a way of classifying different smoke plume observations in terms of the average chemistry of their unidentified SVOCs. Similar studies of other young biomass burning plumes would allow us to see how the chemistry of the unidentified SVOCs varies with combustion efficiency, fuel type, and other combustion and environmental parameters, providing an additional constraint on the reactivities of the unidentified SVOCs. These constraints could then provide more insight into the formation of $\mathrm{O}_{3}, \mathrm{PAN}$, and $\mathrm{OA}$ in young biomass burning smoke plumes and serve as the basis of parameterizing this process for regional or global-scale models. Future field experiments, focused on quasi-Lagrangian sampling of biomass burning smoke plumes, should ideally also provide data beyond that available for the Williams fire that will increase our understanding of the chemistry of these plumes. These field experiments should include (a) observations of changes in particle size distribution to test model simulations of condensational growth, coagulation, and new particle formation; (b) observations of a larger suite of $\mathrm{NO}_{y}$ species, such as $\mathrm{HNO}_{3(\mathrm{~g})}$, peroxy nitrates, and alkyl nitrates, for use in studying and constraining the transformations of reactive nitrogen; (c) direct measurements of photolysis rates within the smoke plumes; (d) measurements of organic aerosol volatility, viscosity, and mixing state with black carbon and inorganic aerosols; and (e) more detailed measurements of the currently unidentified organic species present in the smoke plumes, including acetaldehyde, an important PAN precursor.

\section{The Supplement related to this article is available online} at doi:10.5194/acp-15-6667-2015-supplement. 
Acknowledgements. The authors thank the anonymous reviewers and Manish Kumar Shrivastava of Pacific Northwest National Laboratory (PNNL) for their helpful comments. This modeling work was funded by NSF grant number AGS-1144165 to M. J. Alvarado and C. R. Lonsdale of Atmospheric and Environmental Research (AER) and R. J. Yokelson of the University of Montana. Original sampling of the Williams fire was funded primarily by the Strategic Environmental Research and Development Program (SERDP) projects SI-1648 and SI-1649 and partially by NSF grants ATM-0513055 and ATM-0936321. The California Institute of Technology contributions were partially funded through Dreyfus Award EP-11-117 to J. S. Craven.

Edited by: J. Roberts

\section{References}

Ahmadov, R., McKeen, S. A., Robinson, A. L., Bahreini, R., Middlebrook, A. M., de Gouw, J. A., Meagher, J., Hsie, E.-Y., Edgerton, E., Shaw, S., and Trainer, M.: A volatility basis set model for summertime secondary organic aerosols over the eastern United States in 2006, J. Geophys. Res., 117, 2156-2202, 2012.

Akagi, S. K., Yokelson, R. J., Wiedinmyer, C., Alvarado, M. J., Reid, J. S., Karl, T., Crounse, J. D., and Wennberg, P. O.: Emission factors for open and domestic biomass burning for use in atmospheric models, Atmos. Chem. Phys., 11, 4039-4072, doi:10.5194/acp-11-4039-2011, 2011.

Akagi, S. K., Craven, J. S., Taylor, J. W., McMeeking, G. R., Yokelson, R. J., Burling, I. R., Urbanski, S. P., Wold, C. E., Seinfeld, J. H., Coe, H., Alvarado, M. J., and Weise, D. R.: Evolution of trace gases and particles emitted by a chaparral fire in California, Atmos. Chem. Phys., 12, 1397-1421, doi:10.5194/acp-12-13972012, 2012.

Akagi, S. K., Yokelson, R. J., Burling, I. R., Meinardi, S., Simpson, I., Blake, D. R., McMeeking, G. R., Sullivan, A., Lee, T., Kreidenweis, S., Urbanski, S., Reardon, J., Griffith, D. W. T., Johnson, T. J., and Weise, D. R.: Measurements of reactive trace gases and variable $\mathrm{O}_{3}$ formation rates in some South Carolina biomass burning plumes, Atmos. Chem. Phys., 13, 1141-1165, doi:10.5194/acp-13-1141-2013, 2013.

Allan, J. D., Delia, A. E., Coe, H., Bower, K. N., Alfarra, M. R., Jimenez, J. L., Middlebrook, A. M., Drewnick, F., Onasch, T. B., Canagaratna, M. R., Jayne, J. T., and Worshop, D. R.: A generalized method for the extraction of chemically resolved mass spectra from Aerodyne aerosol mass spectrometer data, J. Aerosol Sci., 35, 909-922, 2004.

Alvarado, M. J.: Formation of Ozone and Growth of Aerosols in Young Smoke Plumes from Biomass Burning, PhD Thesis, Massachusetts Institute of Technology, Cambridge, MA, USA, 324 pp., available at http://globalchange.mit.edu/files/document/ Alvarado_PhD_08.pdf (last access: 11 December 2014), 2008.

Alvarado, M. J. and Prinn, R. G.: Formation of Ozone and Growth of Aerosols in Young Smoke Plumes from Biomass Burning, Part 1: Lagrangian Parcel Studies, J. Geophys. Res., 114, D09306, doi:10.1029/2008JD011144, 2009.

Alvarado, M. J., Wang, C., and Prinn, R. G.: Formation of Ozone and Growth of Aerosols in Young Smoke Plumes from Biomass
Burning, Part 2: 3D Eulerian Studies, J. Geophys. Res., 114, D09307, doi:10.1029/2008JD011186, 2009.

Alvarado, M. J., Logan, J. A., Mao, J., Apel, E., Riemer, D., Blake, D., Cohen, R. C., Min, K.-E., Perring, A. E., Browne, E. C., Wooldridge, P. J., Diskin, G. S., Sachse, G. W., Fuelberg, H., Sessions, W. R., Harrigan, D. L., Huey, G., Liao, J., Case-Hanks, A., Jimenez, J. L., Cubison, M. J., Vay, S. A., Weinheimer, A. J., Knapp, D. J., Montzka, D. D., Flocke, F. M., Pollack, I. B., Wennberg, P. O., Kurten, A., Crounse, J., Clair, J. M. St., Wisthaler, A., Mikoviny, T., Yantosca, R. M., Carouge, C. C., and Le Sager, P.: Nitrogen oxides and PAN in plumes from boreal fires during ARCTAS-B and their impact on ozone: an integrated analysis of aircraft and satellite observations, Atmos. Chem. Phys., 10, 9739-9760, doi:10.5194/acp-10-9739-2010, 2010.

Alvarado, M. J., Cady-Pereira, K. E., Xiao, Y., Millet, D. B., and Payne, V. H.: Emission Ratios for Ammonia and Formic Acid and Observations of Peroxy Acetyl Nitrate (PAN) in Biomass Burning Smoke As Seen By the Tropospheric Emission Spectrometer (TES), Atmosphere, 2, 633-654, doi:10.3390/atmos2040633, 2011.

Andreae, M. O. and Merlet, P.: Emission of trace gases and aerosols from biomass burning, Global Biogeochem. Cycles, 15, 955966, 2001.

Andreae, M. O., Anderson, B. E., Blake, D. R., Bradshaw, J. D. Collins, J. E., Gregory, G. L., Sachse, G. W., and Shipham M. C.: Influence of plumes from biomass burning on atmospheric chemistry over the equatorial and tropical South Atlantic during CITE 3, J. Geophys. Res., 99, 12793-12808, doi:10.1029/94JD00263, 1994.

Arnold, S. R., Emmons, L. K., Monks, S. A., Law, K. S., Ridley, D. A., Turquety, S., Tilmes, S., Thomas, J. L., Bouarar, I., Flemming, J., Huijnen, V., Mao, J., Duncan, B. N., Steenrod, S., Yoshida, Y., Langner, J., and Long, Y.: Biomass burning influence on high-latitude tropospheric ozone and reactive nitrogen in summer 2008: a multi-model analysis based on POLMIP simulations, Atmos. Chem. Phys., 15, 6047-6068, doi:10.5194/acp15-6047-2015, 2015.

Atkinson, R., Baulch, D. L., Cox, R. A., Crowley, J. N., Hampson, R. F., Hynes, R. G., Jenkin, M. E., Rossi, M. J., and Troe, J.: Evaluated kinetic and photochemical data for atmospheric chemistry: Volume $\mathrm{I}$ - gas phase reactions of $\mathrm{O}_{x}, \mathrm{HO}_{x}, \mathrm{NO}_{x}$ and $\mathrm{SO}_{x}$ species, Atmos. Chem. Phys., 4, 1461-1738, doi:10.5194/acp-41461-2004, 2004.

Baylon, P., Jaffe, D. A., Wigder, N. L., Gao, H., and Hee, J.: Ozone enhancement in Western US wildfire plumes at the Mt. Bachelor Observatory: The Role of $\mathrm{NO}_{x}$, Atmos. Environ., 109, 297-304, doi:10.1016/j.atmosenv.2014.09.013, 2015.

Beswick, K. M., Gallagher, M. W., Webb, A. R., Norton, E. G., and Perry, F.: Application of the Aventech AIMMS20AQ airborne probe for turbulence measurements during the Convective Storm Initiation Project, Atmos. Chem. Phys., 8, 5449-5463, doi:10.5194/acp-8-5449-2008, 2008.

Bey, I., Jacob, D. J., Yantosca, R. M., Logan, J. A., Field, B. D., Fiore, A. M., Li, Q., Liu, H. Y., Mickley, L. J., and Schultz, M. G.: Global modeling of tropospheric chemistry with assimilated meteorology: Model description and evaluation, J. Geophys. Res. 106, 23073-23095, 2001.

Bloss, C., Wagner, V., Jenkin, M. E., Volkamer, R., Bloss, W. J., Lee, J. D., Heard, D. E., Wirtz, K., Martin-Reviejo, M., Rea, 
G., Wenger, J. C., and Pilling, M. J.: Development of a detailed chemical mechanism (MCMv3.1) for the atmospheric oxidation of aromatic hydrocarbons, Atmos. Chem. Phys., 5, 641-664, doi:10.5194/acp-5-641-2005, 2005.

Bowman, F. M. and Seinfeld, J. H.: Fundamental basis of incremental reactivities of organics in ozone formation in $\mathrm{VOC} / \mathrm{NO}_{x}$ mixtures, Atmos. Environ., 28, 3359-3368, 1994a.

Bowman, F. M. and Seinfeld, J. H.: Ozone productivity of atmospheric organics, J. Geophys. Res., 99, 5309-5324, 1994b.

Canagaratna, M. R., Jayne, J. T., Jimenez, J. L., Allan, J. D., Alfarra, M. R., Zhang, Q., Onasch, T. B., Drewnick, F., Coe, H., Middlebrook, A., Delia, A., Williams, L. R., Trimborn, A. M., Northway, M. J., DeCarlo, P. F., Kolb, C. E., Davidovits, P., and Worsnop, D. R.: Chemical and microphysical characterization of ambient aerosols with the Aerodyne aerosol mass spectrometer, edited by: Viggiano, A., Mass Spectrom. Rev., 26, 185-222, 2007.

Capes, G., Johnson, B., McFiggans, G., Williams, P. I., Haywood, J., and Coe, H.: Aging of biomass burning aerosols over West Africa: Aircraft measurements of chemical composition, microphysical properties, and emission ratios, J. Geophys. Res., 113, D00C15, doi:10.1029/2008JD009845, 2008.

Carter, W. P.: Development of ozone reactivity scales for volatile organic compounds, J. Air Waste Ma., 44, 881-899, 1994.

Carter, W. P.: Documentation of the SAPRC-99 chemical mechanism for VOC reactivity assessment, Tech. rep., Draft report to the California Air Resources Board, Contracts 92-329 and 95308, University of California, Riverside, CA, USA, 2000.

Carter, W. P. L.: Mechanism and updated ozone reactivity scales, Report to the California Air Resources Board, Contracts No. 03-318, 06-408, and 07-730, University of California, Riverside, CA, USA, 27 January 2010.

Carter, W. P. L., Luo, D., Malkina, I., and Pierce, J.: Environmental chamber studies of atmospheric reactivities of volatile organic compounds: Effects of varying ROG surrogate and $\mathrm{NO}_{x}$, Tech. rep., Final Report to Coordinating Research Council, Inc., Project ME-9, California Air Resources Board, Contract A0320692, and South Coast Air Quality Management District, Contract C91323, available at: http://www.cert.ucr.edu/ carter/absts. htm\#rct2rpt (last access: 15 June 2015), 1995.

Carter, W. P., Cocker, I., David, R., Fitz, D. R., Malkina, I. L., Bumiller, K., Sauer, C. G., Pisano, J. T., Bufalino, C., and Song, C.: A new environmental chamber for evaluation of gas-phase chemical mechanisms and secondary aerosol formation, Atmos. Environ., 39, 7768-7788, 2005.

Christian, T., Kleiss, B., Yokelson, R., Holzinger, R., Crutzen, P., Hao, W., Saharjo, B., and Ward, D.: Comprehensive laboratory measurements of biomas-burning emissions: 1. Emissions from Indonesian, African, and other fuels, J. Geophys. Res., 108, 4719-4731, doi:10.1029/2003JD003704, 2003.

Crounse, J. D., Paulot, F., Kjaergaard, H. G., and Wennberg, P. O.: Peroxy radical isomerization in the oxidation of isoprene, Phys. Chem. Chem. Phys., 13, 13607-13613, 2011.

Crounse, J. D., Knap, H. C., Ørnsø, K. B., Jørgensen, S., Paulot, F., Kjaergaard, H. G., and Wennberg, P. O.: Atmospheric Fate of Methacrolein. 1. Peroxy Radical Isomerization Following Addition of $\mathrm{OH}$ and $\mathrm{O}_{2}$, J. Phys. Chem. A, 116, 5756-5762, 2012.
Crutzen, P. J. and Andreae, M. O.: Biomass burning in the tropics: Impact on atmospheric chemistry and biogeochemical cycles, Science, 250, 1669-1678, 1990.

Donahue, N. M., Epstein, S. A., Pandis, S. N., and Robinson, A. L.: A two-dimensional volatility basis set: 1 . organic-aerosol mixing thermodynamics, Atmos. Chem. Phys., 11, 3303-3318, doi:10.5194/acp-11-3303-2011, 2011.

Drewnick, F., Schwab, J. J., Hogrefe, O., Peters, S., Husain, L., Diamond, D., Weber, R., and Demerjian, K. L.: Intercomparison and evaluation of four semi-continuous $\mathrm{PM}_{2.5}$ sulfate instruments, Atmos. Environ., 37, 3335-3350, 2003.

Drewnick, F., Hings, S. S., DeCarlo, P., Jayne, J. T., Gonin, M., Fuhrer, K., Weimer, S., Jimenez, J. L., Demerjian, K. L., Borrmann, S., and Worsnop, D. R.: A new Time-of-Flight Aerosol Mass Spectrometer (TOF-AMS) - instrument description and first field deployment, Aerosol Sci. Tech., 39, 637-658, 2005.

Dzepina, K., Volkamer, R. M., Madronich, S., Tulet, P., Ulbrich, I. M., Zhang, Q., Cappa, C. D., Ziemann, P. J., and Jimenez, J. L.: Evaluation of recently-proposed secondary organic aerosol models for a case study in Mexico City, Atmos. Chem. Phys., 9, 5681-5709, doi:10.5194/acp-9-5681-2009, 2009.

Ensberg, J. J., Carreras-Sospedra, M., and Dabdub, D.: Impacts of electronically photo-excited $\mathrm{NO}_{2}$ on air pollution in the South Coast Air Basin of California, Atmos. Chem. Phys., 10, 11711181, doi:10.5194/acp-10-1171-2010, 2010.

Fischer, E. V., Jaffe, D. A., Reidmiller, D. R., and Jaeglé, L.: Meteorological controls on observed peroxyacetyl nitrate at Mount Bachelor during the spring of 2008, J. Geophys. Res., 115, D03302, doi:10.1029/2009JD012776, 2010.

Fischer, E. V., Jacob, D. J., Yantosca, R. M., Sulprizio, M. P., Millet, D. B., Mao, J., Paulot, F., Singh, H. B., Roiger, A., Ries, L., Talbot, R.W., Dzepina, K., and Pandey Deolal, S.: Atmospheric peroxyacetyl nitrate (PAN): a global budget and source attribution, Atmos. Chem. Phys., 14, 2679-2698, doi:10.5194/acp-142679-2014, 2014.

Fountoukis, C. and Nenes, A.: ISORROPIA II: a computationally efficient thermodynamic equilibrium model for $\mathrm{K}^{+}$ $\mathrm{Ca}^{2+}-\mathrm{Mg}^{2+}-\mathrm{NH}_{4}^{+}-\mathrm{Na}^{+}-\mathrm{SO}_{4}^{2-}-\mathrm{NO}_{3}^{-}-\mathrm{Cl}^{-}-\mathrm{H}_{2} \mathrm{O}$ aerosols, Atmos. Chem. Phys., 7, 4639-4659, doi:10.5194/acp-7-4639-2007, 2007.

Goliff, W. S., Stockwell, W. R., and Lawson, C. V.: The regional atmospheric chemistry mechanism, version 2, Atmos. Environ., 68, 174-185, 2013.

Goode, J. G., Yokelson, R. J., Ward, D. E., Susott, R. A., Babbitt, R. E., Davies, M. A., and Hao, W. M.: Measurements of excess $\mathrm{O}_{3}, \mathrm{CO}_{2}, \mathrm{CO}, \mathrm{CH}_{4}, \mathrm{C}_{2} \mathrm{H}_{4}, \mathrm{C}_{2} \mathrm{H}_{2}, \mathrm{HCN}, \mathrm{NO}, \mathrm{NH}_{3}, \mathrm{HCOOH}$, $\mathrm{CH}_{3} \mathrm{COOH}, \mathrm{HCHO}$ and $\mathrm{CH}_{3} \mathrm{OH}$ in 1997 Alaskan biomass burning plumes by airborne fourier transform infrared spectroscopy (AFTIR), J. Geophys. Res., 105, 22147-22166, 2000.

Grieshop, A. P., Logue, J. M., Donahue, N. M., and Robinson, A. L.: Laboratory investigation of photochemical oxidation of organic aerosol from wood fires 1: measurement and simulation of organic aerosol evolution, Atmos. Chem. Phys., 9, 1263-1277, doi:10.5194/acp-9-1263-2009, 2009a.

Grieshop, A. P., Donahue, N. M., and Robinson, A. L.: Laboratory investigation of photochemical oxidation of organic aerosol from wood fires 2: analysis of aerosol mass spectrometer data, Atmos. Chem. Phys., 9, 2227-2240, doi:10.5194/acp-9-2227-2009, 2009b. 
Griffin, R. J., Nguyen, K., Dabdub, K. D., and Seinfeld, J. H.: A coupled hydrophobic-hydrophilic model for predicting secondary organic aerosol formation, J. Atmos. Chem., 44, 171190, 2003

Griffin, R. J., Dabdub, D., and Seinfeld, J. H.: Development and initial evaluation of a dynamic species-resolved model for the gas phase chemistry and size-resolved gas/particle partitioning associated with secondary organic aerosol formation, J. Geophys. Res., 110, D05304, doi:10.1029/2004JD005219, 2005.

Heilman, W. E., Liu, Y., Urbanski, S., Kovalev, V., and Mickler, R.: Wildland fire emissions, carbon, and climate: Plume rise, atmospheric transport, and chemistry processes, For. Ecol. Manage., 317, 70-79, doi:10.1016/j.foreco.2013.02.001, 2014.

Hennigan, C. J., Miracolo, M. A., Engelhart, G. J., May, A. A., Presto, A. A., Lee, T., Sullivan, A. P., McMeeking, G. R., Coe, H., Wold, C. E., Hao, W.-M., Gilman, J. B., Kuster, W. C., de Gouw, J., Schichtel, B. A., Collett Jr., J. L., Kreidenweis, S. M., and Robinson, A. L.: Chemical and physical transformations of organic aerosol from the photo-oxidation of open biomass burning emissions in an environmental chamber, Atmos. Chem. Phys., 11, 7669-7686, doi:10.5194/acp-11-7669-2011, 2011.

Heringa, M. F., DeCarlo, P. F., Chirico, R., Tritscher, T., Dommen, J., Weingartner, E., Richter, R., Wehrle, G., Prévôt, A. S. H., and Baltensperger, U.: Investigations of primary and secondary particulate matter of different wood combustion appliances with a high-resolution time-of-flight aerosol mass spectrometer, Atmos. Chem. Phys., 11, 5945-5957, doi:10.5194/acp-11-59452011, 2011.

Hobbs, P. V., Sinha, P., Yokelson, R. J., Christian, T. J., Blake, D. R., Gao, S., Kirchstetter, T. W., Novakov, T., and Pilewskie, P.: Evolution of gases and particles from a savanna fire in South Africa, J. Geophys. Res., 108, 8485-8504, doi:10.1029/2002JD002352, 2003

Holmes, C. D., Prather, M. J., and Vinken, G. C. M.: The climate impact of ship $\mathrm{NO}_{x}$ emissions: an improved estimate accounting for plume chemistry, Atmos. Chem. Phys., 14, 6801-6812, doi:10.5194/acp-14-6801-2014, 2014

Huffman, J. A., Jayne, J. T., Drewnick, F., Aiken, A. C., Onasch, T., Worsnop, D. R., and Jimenez, J. L.: Design, modeling, optimization, and experimental tests of a particle beam width probe for the aerodyne aerosol mass spectrometer, Aerosol Sci. Technol., 39, 1143-1163, 2005.

Jacob, D. J.: Heterogeneous chemistry and tropospheric ozone, Atmos. Environ., 34, 2131-2159, 2000.

Jacob, D. J., Wofsy, S., Bakwin, P., Fan, S.-M., Harriss, R., Talbot, R., Bradshaw, J., Sandholm, S., Singh, H., Browell, E.V. Gregory, G., Sachse, G., Shipham, M., Blake, D., and Fitzjarrald, D.: Summertime photochemistry of the troposphere at high northern latitudes, J. Geophys. Res., 97, 16421-16431, 1992.

Jacobson, M. Z.: Development and application of a new air pollution modeling system - II. Aerosol module structure and design, Atmos. Environ., 31, 131-144, 1997.

Jacobson, M. Z.: Analysis of aerosol interactions with numerical techniques for solving coagulation, nucleation, condensation, dissolution, and reversible chemistry among multiple size distributions, J. Geophys. Res., 107, 4366-4388, doi:10.1029/2001JD002044, 2002.

Jacobson, M. Z.: Fundamentals of Atmospheric Modeling, 2nd ed., Cambridge University Press, Cambridge, UK, 2005.
Jaffe, D. A. and Wigder, N. L.: Ozone production from wildfires: A critical review, Atmos. Environ., 51, 1-10, 2012.

Jaffe, D. A., Wigder, N., Downey, N., Pfister, G., Boynard, A., and Reid, S. B.: Impact of wildfires on ozone exceptional events in the western US, Environ. Sci. Tech., 47, 11065-11072, 2013.

Jenkin, M. E., Saunders, S. M., and Pilling, M. J.: The tropospheric degradation of volatile organic compounds: a protocol for mechanism development, Atmos. Environ., 31, 81-104, doi:10.1016/S1352-2310(96)00105-7, 1997.

Jenkin, M. E., Saunders, S. M., Wagner, V., and Pilling, M. J.: Protocol for the development of the Master Chemical Mechanism, MCM v3 (Part B): tropospheric degradation of aromatic volatile organic compounds, Atmos. Chem. Phys., 3, 181-193, doi:10.5194/acp-3-181-2003, 2003.

Jiang, X., Wiedinmyer, C., and Carlton, A. G.: Aerosols from fires: An examination of the effects on ozone photochemistry in the Western United States, Environ. Sci. Technol., 46, 11878-11886, 2012.

Jimenez, J. L., Canagaratna, M. R., Donahue, N. M., Prevot, A. S. H., Zhang, Q., Kroll, J. H., DeCarlo, P. F., Allan, J. D., Coe, H., Ng, N. L., Aiken, A. C., Docherty, K. S., Ulbrich, I. M., Grieshop, A. P., Robinson, A. L., Duplissy, J., Smith, J. D., Wilson, K. R., Lanz, V. A., Hueglin, C., Sun, Y. L., Tian, J., Laaksonen, A., Raatikainen, T., Rautiainen, J, Vaattovaara, P., Ehn, M., Kulmala, M., Tomlinson, J. M., Collins, D. R., Cubison, M J., Dunlea, E. J., Huffman, J. A., Onasch, T. B., Alfarra, M. R., Williams, P. I., Bower, K., Kondo, Y., Schneider, J., Drewnick, F., Borrmann, S., Weimer, S., Demerjian, K., Salcedo, D., Cottrell, L., Griffin, R., Takami, A., Miyoshi, T, Hatakeyama, S., Shimono, A., Sun, J. Y., Zhang, Y. M., Dzepina, K., Kimmel, J. R., Sueper, D., Jayne, J. T., Herndon, S. C., Trimborn, A. M., Williams, L. R., Wood, E. C., Middlebrook, A. M., Kolb, C. E., Baltensperger, U., and Worsnop, D. R.: Evolution of Organic Aerosols in the Atmosphere, Science, 326, 1525-1529, 2009.

Jost, C., Trentmann, J., Sprung, D., Andreae, M. O., McQuaid, J. B., and Barjat, H.: Trace gas chemistry in a young biomass burning plume over Namibia: Observations and model simulations, J. Geophys. Res., 108, 8482-8494, doi:10.1029/2002JD002431, 2003.

Kidd, C., Perraud, V., Wingen, L. M., and Finlayson-Pitts, B. J.: Integrating phase and composition of secondary organic aerosol from the ozonolysis of $\alpha$-pinene, P. Natl. Acad. Sci., 111, 75527557, doi:10.1073/pnas.1322558111, 2014.

Kusik, C. and Meissner, H.: Electrolyte activity coefficients in inorganic processing, in Fundamental Aspects of Hydrometallurgical Processes, AIChE Symposium Series, edited by: Chapman, T., Taularides, L., Hubred, G., and Wellek, R., 14-20, AIChE, New York, USA, 1978.

Lapina, K., Honrath, R., Owen, R. C., Val Martin, M., and Pfister, G.: Evidence of significant large-scale impacts of boreal fires on ozone levels in the midlatitude Northern Hemisphere free troposphere, Geophys. Res. Lett., 33, L10815, doi:10.1029/2006GL025878, 2006.

Madronich, S. and Flocke, S.: The role of solar radiation in atmospheric chemistry, in: Handbook of Environmental Chemistry, edited by: Boule, P., Springer, 1-26, Berlin, Germany, doi:10.1007/978-3-540-69044-3_1, 1998.

Mason, S. A., Field, R. J., Yokelson, R. J., Kochivar, M. A., Tinsley, M. R., Ward, D. W., and Hao, W. M.: Complex effects arising 
in smoke plume simulations due to the inclusion of direct emissions of oxygenated organic species from biomass combustion, J. Geophys. Res., 106, 12527-12539, 2001.

Mason, S. A., Trentmann, J., Winterrath, T., Yokelson, R. J., Christian, T. J., Carlson, L. J., Warner, T. R., Wolfe, L. C., and Andreae, M. O.: Intercomparison of two box models of the chemical evolution in biomass-burning smoke plumes, J. Atmos. Chem., 55, 273-297, doi:10.1007/s10874-006-9039-5, 2006.

Mauzerall, D. L., Logan, J. A., Jacob, D J., Anderson, B. E., Blake, D. R., Bradshaw, J. D., Heikes, B., Sachse, G. W., Singh, H., and Talbot, B.: Photochemistry in biomass burning plumes and implications for tropospheric ozone over the tropical South Atlantic, J. Geophys. Res. 103, 8401-8423, 1998.

May, A. A., Levin, E. J. T., Hennigan, C. J., Riipinen, I., Lee, T., Collett Jr., J. L., Jimenez, J. L., Kreidenweis, S. M., and Robinson, A. L.: Gas-particle partitioning of primary organic aerosol emissions: 3. Biomass burning, J. Geophys. Res., 118, 1132711338, doi:10.1002/jgrd.50828, 2013.

Nenes, A., Pandis, S. N., and Pilinis, C.: ISORROPIA: A new thermodynamic equilibrium model for multiphase multicomponent inorganic aerosols, Aquat. Geochem., 4, 123-152, 1998.

Pankow, J. F.: An absorption model of gas/particle partitioning of organic compounds in the atmosphere, Atmos. Environ., 28, 185-188, 1994a.

Pankow, J. F.: An absorption model of the gas/aerosol partitioning involved in the formation of secondary organic aerosol, Atmos. Environ., 28, 189-193, 1994b.

Parrington, M., Palmer, P. I., Lewis, A. C., Lee, J. D., Rickard, A. R., Di Carlo, P., Taylor, J. W., Hopkins, J. R., Punjabi, S., Oram, D. E., Forster, G., Aruffo, E., Moller, S. J., Bauguitte, S. J.-B., Allan, J. D., Coe, H., and Leigh, R. J.: Ozone photochemistry in boreal biomass burning plumes, Atmos. Chem. Phys., 13, 73217341, doi:10.5194/acp-13-7321-2013, 2013.

Paulot, F., Crounse, J. D., Kjaergaard, H. G., Kroll, J. H., Seinfeld, J. H., and Wennberg, P. O.: Isoprene photooxidation: new insights into the production of acids and organic nitrates, Atmos. Chem. Phys., 9, 1479-1501, doi:10.5194/acp-9-1479-2009, 2009a.

Paulot, F., Kurten, A., St Clair, J. M., Seinfeld, J. H., and Wennberg, P. O.: Unexpected Epoxide Formation in the Gas-Phase Photooxidation of Isoprene, Science, 325, 730-733, $2009 \mathrm{~b}$.

Petters, M. D. and Kreidenweis, S. M.: A single parameter representation of hygroscopic growth and cloud condensation nucleus activity, Atmos. Chem. Phys., 7, 1961-1971, doi:10.5194/acp-71961-2007, 2007.

Pfister, G., Emmons, L. K., Hess, P. G., Honrath, R., Lamarque, J. F., Val Martin, M., Owen, R. C., Avery, M. A., Browell, E. V., Holloway, J. S., Nedelec, P., Purvis, R., Ryerson, R. B., Sachse, G. W., and Schlager, H.: Ozone production from the 2004 North American boreal fires, J. Geophys. Res., 111, D24S07, doi:10.1029/2006JD007695, 2006.

Pun, B. K., Griffin, R. J., Seigneur, C., and Seinfeld, J. H.: Secondary organic aerosol, 2, Thermodynamic model for Gas/Particle partitioning of molecular constituents, J. Geophys. Res., 107, 4333-4347, doi:10.1029/2001JD000542, 2002.

Reid, J. S. and Hobbs, P. V.: Physical and optical properties of young smoke from individual biomass fires in Brazil, J. Geophys. Res., 103, 32013-32030, 1998.

Reid, J. S., Eck, T. F., Christopher, S. A., Koppmann, R., Dubovik, O., Eleuterio, D. P., Holben, B. N., Reid, E. A., and Zhang, J.:
A review of biomass burning emissions part III: intensive optical properties of biomass burning particles, Atmos. Chem. Phys., 5, 827-849, doi:10.5194/acp-5-827-2005, 2005a.

Resch, T.: A framework for modeling suspended multicomponent particulate systems with applications to atmospheric aerosols, $\mathrm{PhD}$ thesis, Massachusetts Institute of Technology, Cambridge, MA, USA, 1995.

Robinson, A. L., Donahue, N. M., Shrivastava, M. K., Weitkamp, E. A., Sage, A. M., Grieshop, A. P., Lane, T. E., Pierce, J. R., and Pandis, S. N.: Rethinking Organic Aerosols: Semivolatile Emissions and Photochemical Aging, Science, 315, 1259-1262, 2007.

Sander, S. P., Abbatt, J., Barker, J. R., Burkholder, J. B., Friedl, R. R., Golden, D. M., Huie, R. E., Kolb, C. E., Kurylo, M. J., Moortgat, G. K., Orkin, V. L., and Wine, P. H.: Chemical Kinetics and Photochemical Data for Use in Atmospheric Studies, Evaluation No. 17, JPL Publication 10-6, Jet Propulsion Laboratory, Pasadena, http://jpldataeval.jpl.nasa.gov (last access: 12 June 2015), 2011.

Saunders, S. M., Jenkin, M. E., Derwent, R. G., and Pilling, M. J.: Protocol for the development of the Master Chemical Mechanism, MCM v3 (Part A): tropospheric degradation of nonaromatic volatile organic compounds, Atmos. Chem. Phys., 3, 161-180, doi:10.5194/acp-3-161-2003, 2003.

Seinfeld, J. H. and Pandis, S. N.: Atmospheric Chemistry and Physics, John Wiley and Sons, New York, NY, USA, 1998.

Shrivastava, M. K. B., Zelenyuk, A., Imre, D., Easter Jr., R. C., Beranek, J., Zaveri, R. A., and Fast, J. D.: Implications of Low Volatility SOA and Gas-Phase Fragmentation Reactions on SOA Loadings and their Spatial and Temporal Evolution in the Atmosphere. J. Geophys. Res., 118, 3328-3342, doi:10.1002/jgrd.50160, 2013.

Singh, H. B., Cai, C., Kaduwela, A., Weinheimer, A., and Wisthaler, A.: Interactions of fire emissions and urban pollution over California: Ozone formation and air quality simulations, Atmos. Environ., 56, 45-51, 2012.

Steele, H. D.: Investigations of cloud altering effects of atmospheric aerosols using a new mixed eulerian-lagrangian aerosol model, $\mathrm{PhD}$ thesis, Massachusetts Institute of Technology, available at: http://web.mit.edu/cgcs/www/MIT_CGCS_Rpt74.pdf (last access: 12 June 2015), 2004.

Stemmler, K., Ammann, M., Donders, C., Kleffmann, J., and George, C.: Photosensitized reduction of nitrogen dioxide on humic acid as a source of nitrous acid, Nature, 440, 195-198, doi:10.1038/nature04603, 2006.

Stemmler, K., Ndour, M., Elshorbany, Y., Kleffmann, J., D’Anna, B., George, C., Bohn, B., and Ammann, M.: Light induced conversion of nitrogen dioxide into nitrous acid on submicron humic acid aerosol, Atmos. Chem. Phys., 7, 4237-4248, doi:10.5194/acp-7-4237-2007, 2007.

Stokes, R. H. and Robinson, R. A.: Interactions in aqueous nonelectrolyte solutions. I. Solute-Solvent Equilibria, J. Phys. Chem., 70, 2126-2130, 1966.

Sudo, K. and Akimoto. H.: Global source attribution of tropospheric ozone: Long-range transport from various source regions, J. Geophys. Res., 112, D12302, doi:10.1029/2006JD007992, 2007.

Trentmann, J., Andreae, M. O., and Graf, H.-F.: Chemical processes in a young biomass-burning plume, J. Geophys. Res., 108, 47054714, doi:10.1029/2003JD003732, 2003. 
Trentmann, J., Yokelson, R. J., Hobbs, P. V., Winterrath, T., Christian, T. J., Andreae, M. O., and Mason, S. A.: An analysis of the chemical processes in the smoke plume from a savannah fire, J. Geophys. Res., 110, D12301, doi:10.1029/2004JD005628, 2005.

Vakkari, V., Kerminen, V., Beukes, J. P., Tiitta, P., van Zyl, P. G., Josipovic, M., Venter, A. D., Jaars, K., Worsnop, D. R., Kulmala M., and Laakso, L.: Rapid changes in biomass burning aerosols by atmospheric oxidation, Geophys. Res. Lett., 41, 2644-2651, doi:10.1002/2014GL059396, 2014.

Val Martin, M., Honrath, R. E., Owen, R. C., Pfister, G., Fialho, P., and Barata, F.: Significant enhancements of nitrogen oxides, ozone and aerosol black carbon in the North Atlantic lower free troposphere resulting from North American boreal wildfires, J. Geophys. Res., 111, D23S60, doi:10.1029/2006JD007530, 2006. van der Werf, G. R., Randerson, J. T., Giglio, L., Collatz, G. J., Mu, M., Kasibhatla, P. S., Morton, D. C., DeFries, R. S., Jin, Y., and van Leeuwen, T. T.: Global fire emissions and the contribution of deforestation, savanna, forest, agricultural, and peat fires (19972009), Atmos. Chem. Phys., 10, 11707-11735, doi:10.5194/acp10-11707-2010, 2010.

Vinken, G. C. M., Boersma, K. F., Jacob, D. J., and Meijer, E. W.: Accounting for non-linear chemistry of ship plumes in the GEOS-Chem global chemistry transport model, Atmos. Chem. Phys., 11, 11707-11722, doi:10.5194/acp-11-11707-2011, 2011.

Warneke, C., Roberts, J. M., Veres, P., Gilman, J., Kuster, W. C., Burling, I., Yokelson, R. J., and de Gouw, J. A.: VOC identification and inter-comparison from laboratory biomass burning using PTR-MS and PIT-MS, Int. J. Mass Spectrom. Ion Proc., 303, 6-14, doi:10.1016/j.ijms.2010.12.002, 2011.

Wilson, J. C., Lafleur, B. G., Hilbert, H., Seebaugh, W. R., Fox, J., Gesler, D. W., Brock, C. A., Huebert, B. J., and Mullen, J.: Function and performance of a low turbulence inlet for sampling supermicron particles from aircraft platforms, Aerosol Sci. Tech., 38, 790-802, 2004.

Yarwood, G., Rao, S., Yocke, M., and Whitten, G. Z.: Updates to the carbon bond chemical mechanism: CB05, RT-04-00675, Prepared for Deborah Luecken, U.S. Environmental Protection Agency Research Triangle Park, NC 27703, ENVIRON, available at http://www.camx.com/publ/pdfs/cb05_final_report_ 120805.pdf (last access: 12 June 2015), 2005.
Yokelson, R. J., Goode, J. G., Ward, D. E., Susott, R. A., Babbitt, R. E., Wade, D. D., Bertschi, I., Griffith, D. W. T., and Hao, W. M.: Emissions of formaldehyde, acetic acid, methanol, and other trace gases from biomass fires in North Carolina measured by airborne Fourier transform infrared spectroscopy, J. Geophys. Res., 104, 30109-30126, doi:10.1029/1999JD900817, 1999.

Yokelson, R. J., Bertschi, I. T., Christian, T. J., Hobbs, P. V., Ward, D. E., and Hao, W. M.: Trace gas measurements in nascent, aged, and cloud-processed smoke from African savanna fires by airborne fourier transform infrared spectroscopy (AFTIR), J. Geophys. Res., 108, 8478-8491, doi:10.1029/2002JD002322, 2003.

Yokelson, R. J., Urbanski, S. P., Atlas, E. L., Toohey, D. W., Alvarado, E. C., Crounse, J. D., Wennberg, P. O., Fisher, M. E., Wold, C. E., Campos, T. L., Adachi, K., Buseck, P. R., and Hao, W. M.: Emissions from forest fires near Mexico City, Atmos. Chem. Phys., 7, 5569-5584, doi:10.5194/acp-7-5569-2007, 2007.

Yokelson, R. J., Crounse, J. D., DeCarlo, P. F., Karl, T., Urbanski, S., Atlas, E., Campos, T., Shinozuka, Y., Kapustin, V., Clarke, A. D., Weinheimer, A., Knapp, D. J., Montzka, D. D., Holloway, J., Weibring, P., Flocke, F., Zheng, W., Toohey, D., Wennberg, P. O., Wiedinmyer, C., Mauldin, L., Fried, A., Richter, D., Walega, J., Jimenez, J. L., Adachi, K., Buseck, P. R., Hall, S. R., and Shetter, R.: Emissions from biomass burning in the Yucatan, Atmos. Chem. Phys., 9, 5785-5812, doi:10.5194/acp-9-5785-2009, 2009.

Zaveri, R. A., Easter, R. C., Shilling, J. E., and Seinfeld, J. H.: Modeling kinetic partitioning of secondary organic aerosol and size distribution dynamics: representing effects of volatility, phase state, and particle-phase reaction, Atmos. Chem. Phys., 14, 5153-5181, doi:10.5194/acp-14-5153-2014, 2014.

Zdanovskii, A. B.: New methods for calculating solubilities of electrolytes in multi-component systems, Zhur. Fiz. Kim., 22, 14751485, 1948.

Zhang, L., Jacob, D. J., Yue, X., Downey, N. V., Wood, D. A., and Blewitt, D.: Sources contributing to background surface ozone in the US Intermountain West, Atmos. Chem. Phys., 14, 52955309, doi:10.5194/acp-14-5295-2014, 2014. 